\title{
Voltage-gated calcium channels (version 2020.5) in the IUPHAR/BPS Guide to Pharmacology Database
}

\author{
William A. Catterall ${ }^{1}$, Edward Perez-Reyes ${ }^{2}$, Terrance P. Snutch ${ }^{3}$ and Jörg Striessnig ${ }^{4}$ \\ 1. University of Washington, USA \\ 2. University of Virginia, USA \\ 3. University of British Columbia, Canada \\ 4. University of Innsbruck, Austria
}

\begin{abstract}
Calcium $\left(\mathrm{Ca}^{2+}\right)$ channels are voltage-gated ion channels present in the membrane of most excitable cells. The nomenclature for $\mathrm{Ca}^{2+}$ channels was proposed by [120] and approved by the NC-IUPHAR Subcommittee on $\mathrm{Ca}^{2+}$ channels [68]. $\mathrm{Ca}^{2+}$ channels form hetero-oligomeric complexes. The a1 subunit is pore-forming and provides the binding site(s) for practically all agonists and antagonists. The 10 cloned $\alpha 1$-subunits can be grouped into three families: (1) the high-voltage activated dihydropyridine-sensitive (L-type, Cav1.x) channels; (2) the high-voltage activated dihydropyridine-insensitive ( $\left.\mathrm{Ca}_{\vee} 2 . x\right)$ channels and (3) the low-voltage-activated (T-type, Cav3.x) channels. Each a1 subunit has four homologous repeats (I-IV), each repeat having six transmembrane domains and a pore-forming region between transmembrane domains S5 and S6. Voltagedependent gating is driven by the membrane spanning S4 segment, which contains highly conserved positive charges that respond to changes in membrane potential. Many of the $\alpha 1$-subunit genes give rise to alternatively spliced products. At least for high-voltage activated channels, it is likely that native channels comprise coassemblies of $\alpha 1, \beta$ and $\alpha 2-\delta$ subunits. The $y$ subunits have not been proven to associate with channels other than the $\alpha 1 \mathrm{~s}$ skeletal muscle Cav1.1 channel. The $\alpha 2-\delta 1$ and $\alpha 2-\delta 2$ subunits bind gabapentin and pregabalin.
\end{abstract}

\section{Contents}

This is a citation summary for Voltage-gated calcium channels in the Guide to Pharmacology database (GtoPdb). It exists purely as an adjunct to the database to facilitate the recognition of citations to and from the database by citation analyzers. Readers will almost certainly want to visit the relevant sections of the database which are given here under database links.

GtoPdb is an expert-driven guide to pharmacological targets and the substances that act on them. GtoPdb is a reference work which is most usefully represented as an on-line database. As in any publication this work should be appropriately cited, and the papers it cites should also be recognized. This document provides a citation for the relevant parts of the database, and also provides a reference list for the research cited by those parts.

Please note that the database version for the citations given in GtoPdb are to the most recent preceding version in which the family or its subfamilies and targets were substantially changed. The links below are to the current version. If you need to consult the cited version, rather than the most recent version, please contact the GtoPdb curators.

\section{Database links}

\author{
Voltage-gated calcium channels \\ https://www.guidetopharmacology.org/GRAC/FamilyDisplayForward?familyld=80 \\ Introduction to Voltage-gated calcium channels \\ https://www.guidetopharmacology.org/GRAC/FamilyIntroductionForward?familyld=80 \\ Channels and Subunits \\ $\mathrm{Ca}_{\mathrm{v}} 1.1$ \\ https://www.guidetopharmacology.org/GRAC/ObjectDisplayForward?objectld=528 \\ $\mathrm{Ca}_{\mathrm{v}} 1.2$ \\ https://www.guidetopharmacology.org/GRAC/ObjectDisplayForward?objectld=529
}


$\mathrm{Ca}_{\mathrm{v}} 1.3$

https://www.guidetopharmacology.org/GRAC/ObjectDisplayForward?objectld=530

$\mathrm{Ca}_{\mathrm{v}} 1.4$

https://www.guidetopharmacology.org/GRAC/ObjectDisplayForward?objectld=531

Ca 2.1

https://www.guidetopharmacology.org/GRAC/ObjectDisplayForward?objectld=532

$\mathrm{Ca}_{\mathrm{v}} 2.2$

https://www.guidetopharmacology.org/GRAC/ObjectDisplayForward?objectld=533

$\mathrm{Ca}_{\mathrm{v}} 2.3$

https://www. guidetopharmacology.org/GRAC/ObjectDisplayForward? objectld=534

$\mathrm{Ca}_{\mathrm{v}} 3.1$

https://www.guidetopharmacology.org/GRAC/ObjectDisplayForward?objectld=535

$\mathrm{Ca}_{\mathrm{v}} 3.2$

https://www.guidetopharmacology.org/GRAC/ObjectDisplayForward?objectld=536

$\mathrm{Ca}_{\mathrm{v}} 3.3$

https://www.guidetopharmacology.org/GRAC/ObjectDisplayForward?objectld=537

\section{References}

1. Abbadie C, McManus OB, Sun SY, Bugianesi RM, Dai G, Haedo RJ, Herrington JB, Kaczorowski GJ, Smith MM and Swensen AM et al.. (2010) Analgesic effects of a substituted N-triazole oxindole (TROX-1), a state-dependent, voltage-gated calcium channel 2 blocker. J. Pharmacol. Exp. Ther. 334: 545-55 [PMID:20439438]

2. Adams ME, Mintz IM, Reily MD, Thanabal V and Bean BP. (1993) Structure and properties of omegaagatoxin IVB, a new antagonist of P-type calcium channels. Mol. Pharmacol. 44: 681-8 [PMID:8232218]

3. Adams PJ, Garcia E, David LS, Mulatz KJ, Spacey SD and Snutch TP. (2009) Ca(V)2.1 P/Q-type calcium channel alternative splicing affects the functional impact of familial hemiplegic migraine mutations: implications for calcium channelopathies. Channels (Austin) 3: 110-21 [PMID:19242091]

4. Adams PJ, Rungta RL, Garcia E, van den Maagdenberg AM, MacVicar BA and Snutch TP. (2010) Contribution of calcium-dependent facilitation to synaptic plasticity revealed by migraine mutations in the P/Q-type calcium channel. Proc. Natl. Acad. Sci. U.S.A. 107: 18694-9 [PMID:20937883]

5. Adams PJ and Snutch TP. (2007) Calcium channelopathies: voltage-gated calcium channels. Subcell. Biochem. 45: 215-51 [PMID:18193639]

6. Albillos A, Neher E and Moser T. (2000) R-Type Ca2+ channels are coupled to the rapid component of secretion in mouse adrenal slice chromaffin cells. J. Neurosci. 20: 8323-30 [PMID:11069939]

7. ALLHAT Officers and Coordinators for the ALLHAT Collaborative Research Group. The Antihypertensive and Lipid-Lowering Treatment to Prevent Heart Attack Trial. (2002) Major outcomes in high-risk hypertensive patients randomized to angiotensin-converting enzyme inhibitor or calcium channel blocker vs diuretic: The Antihypertensive and Lipid-Lowering Treatment to Prevent Heart Attack Trial (ALLHAT). JAMA 288: 2981-97 [PMID:12479763]

8. Andreasen D, Friis UG, Uhrenholt TR, Jensen BL, Skøtt O and Hansen PB. (2006) Coexpression of voltage-dependent calcium channels Cav1.2, 2.1a, and 2.1b in vascular myocytes. Hypertension 47: 73541 [PMID:16505211]

9. Antzelevitch C, Pollevick GD, Cordeiro JM, Casis O, Sanguinetti MC, Aizawa Y, Guerchicoff A, Pfeiffer R, Oliva A and Wollnik B et al.. (2007) Loss-of-function mutations in the cardiac calcium channel underlie a new clinical entity characterized by ST-segment elevation, short QT intervals, and sudden cardiac death. Circulation 115: 442-9 [PMID:17224476]

10. Atluri N, Joksimovic SM, Oklopcic A, Milanovic D, Klawitter J, Eggan P, Krishnan K, Covey DF, Todorovic SM and Jevtovic-Todorovic V. (2018) A neurosteroid analogue with T-type calcium channel blocking properties is an effective hypnotic, but is not harmful to neonatal rat brain. $\mathrm{Br} J$ Anaesth 120: 768-778 [PMID:29576117]

11. Audo I, Bujakowska KM, Léveillard T, Mohand-Saïd S, Lancelot ME, Germain A, Antonio A, Michiels C, Saraiva JP and Letexier M et al.. (2012) Development and application of a next-generation-sequencing (NGS) approach to detect known and novel gene defects underlying retinal diseases. Orphanet $J$ Rare Dis 7: 8 [PMID:22277662]

12. Azizan EA, Poulsen H, Tuluc $P$, Zhou J, Clausen MV, Lieb A, Maniero C, Garg S, Bochukova EG and Zhao W et al.. (2013) Somatic mutations in ATP1A1 and CACNA1D underlie a common subtype of adrenal hypertension. Nat. Genet. 45: 1055-60 [PMID:23913004]

13. Bader PL, Faizi M, Kim LH, Owen SF, Tadross MR, Alfa RW, Bett GC, Tsien RW, Rasmusson RL and Shamloo M. (2011) Mouse model of Timothy syndrome recapitulates triad of autistic traits. Proc. Natl. Acad. Sci. U.S.A. 108: 15432-7 [PMID:21878566]

14. Badou A, Jha MK, Matza D, Mehal WZ, Freichel M, Flockerzi V and Flavell RA. (2006) Critical role for the beta regulatory subunits of Cav channels in T lymphocyte function. Proc. Natl. Acad. Sci. U.S.A. 103: 15529-34 [PMID:17028169]

15. Baig SM, Koschak A, Lieb A, Gebhart M, Dafinger C, Nürnberg G, Ali A, Ahmad I, Sinnegger-Brauns MJ and Brandt $\mathrm{N}$ et al.. (2011) Loss of $\mathrm{Ca}(\mathrm{v}) 1.3$ (CACNA1D) function in a human channelopathy with 
bradycardia and congenital deafness. Nat. Neurosci. 14: 77-84 [PMID:21131953]

16. Balijepalli RC, Foell JD, Hall DD, Hell JW and Kamp TJ. (2006) Localization of cardiac L-type Ca(2+) channels to a caveolar macromolecular signaling complex is required for beta(2)-adrenergic regulation. Proc. Natl. Acad. Sci. U.S.A. 103: 7500-5 [PMID:16648270]

17. Ball SL, Powers PA, Shin HS, Morgans CW, Peachey NS and Gregg RG. (2002) Role of the beta(2) subunit of voltage-dependent calcium channels in the retinal outer plexiform layer. Invest. Ophthalmol. Vis. Sci. 43: 1595-603 [PMID:11980879]

18. Barg S, Ma X, Eliasson L, Galvanovskis J, Göpel SO, Obermüller S, Platzer J, Renström E, Trus M and Atlas D et al.. (2001) Fast exocytosis with few $\mathrm{Ca}(2+)$ channels in insulin-secreting mouse pancreatic $B$ cells. Biophys. J. 81: 3308-23 [PMID:11720994]

19. Barrett CF, Cao YQ and Tsien RW. (2005) Gating deficiency in a familial hemiplegic migraine type 1 mutant P/Q-type calcium channel. J. Biol. Chem. 280: 24064-71 [PMID:15795222]

20. Baumann L, Gerstner A, Zong X, Biel M and Wahl-Schott C. (2004) Functional characterization of the Ltype Ca2+ channel Cav1.4alpha1 from mouse retina. Invest. Ophthalmol. Vis. Sci. 45: 708-13 [PMID:14744918]

21. Baur CP, Klingler W, Jurkat-Rott K, Froeba G, Schoch E, Marx T, Georgieff M and Lehmann-Horn F. (2000) Xenon does not induce contracture in human malignant hyperthermia muscle. Br J Anaesth 85: 712-6 [PMID:11094586]

22. Beam KG and Knudson CM. (1988) Calcium currents in embryonic and neonatal mammalian skeletal muscle. J. Gen. Physiol. 91: 781-98 [PMID:2458429]

23. Beam KG and Knudson CM. (1988) Effect of postnatal development on calcium currents and slow charge movement in mammalian skeletal muscle. J. Gen. Physiol. 91: 799-815 [PMID:2458430]

24. Bean BP. (1984) Nitrendipine block of cardiac calcium channels: high-affinity binding to the inactivated state. Proc. Natl. Acad. Sci. U.S.A. 81: 6388-92 [PMID:6093100]

25. Bech-Hansen NT, Naylor MJ, Maybaum TA, Pearce WG, Koop B, Fishman GA, Mets M, Musarella MA and Boycott KM. (1998) Loss-of-function mutations in a calcium-channel alpha1-subunit gene in Xp11.23 cause incomplete X-linked congenital stationary night blindness. Nat. Genet. 19: 264-7 [PMID:9662400]

26. Bech-Hansen T and Naylor MJ. (1999) Retinal calcium channel (alpha)1f-subunit gene. Patent number: CA2299611 A1.

27. Bell TJ, Thaler C, Castiglioni AJ, Helton TD and Lipscombe D. (2004) Cell-specific alternative splicing increases calcium channel current density in the pain pathway. Neuron 41: 127-38 [PMID:14715140]

28. Benjamin ER, Pruthi F, Olanrewaju S, Shan S, Hanway D, Liu X, Cerne R, Lavery D, Valenzano KJ and Woodward RM et al.. (2006) Pharmacological characterization of recombinant N-type calcium channel (Cav2.2) mediated calcium mobilization using FLIPR. Biochem. Pharmacol. 72: 770-82 [PMID:16844100]

29. Beuckelmann DJ, Näbauer M and Erdmann E. (1991) Characteristics of calcium-current in isolated human ventricular myocytes from patients with terminal heart failure. J. Mol. Cell. Cardiol. 23: 929-37 [PMID:1658345]

30. Beuckmann CT, Sinton CM, Miyamoto N, Ino M and Yanagisawa M. (2003) N-type calcium channel alpha1B subunit (Cav2.2) knock-out mice display hyperactivity and vigilance state differences. J. Neurosci. 23: 6793-7 [PMID:12890773]

31. Bijveld MM, Florijn RJ, Bergen AA, van den Born LI, Kamermans M, Prick L, Riemslag FC, van Schooneveld MJ, Kappers AM and van Genderen MM. (2013) Genotype and phenotype of 101 dutch patients with congenital stationary night blindness. Ophthalmology 120: 2072-81 [PMID:23714322]

32. Birnbaumer L, Campbell KP, Catterall WA, Harpold MM, Hofmann F, Horne WA, Mori Y, Schwartz A, Snutch TP and Tanabe T et al.. (1994) The naming of voltage-gated calcium channels.Neuron 13: 505-6 [PMID:7917287]

33. Blaich A, Pahlavan S, Tian Q, Oberhofer M, Poomvanicha M, Lenhardt P, Domes K, Wegener JW, Moosmang $S$ and Ruppenthal $S$ et al.. (2012) Mutation of the calmodulin binding motif IQ of the L-type $\mathrm{Ca}(\mathrm{v}) 1.2 \mathrm{Ca} 2+$ channel to EQ induces dilated cardiomyopathy and death. J. Biol. Chem. 287: 22616-25 [PMID:22589547]

34. Bleakman D, Bowman D, Bath CP, Brust PF, Johnson EC, Deal CR, Miller RJ, Ellis SB, Harpold MM and Hans $M$ et al.. (1995) Characteristics of a human N-type calcium channel expressed in HEK293 cells. Neuropharmacology 34: 753-65 [PMID:8532142]

35. Bock G, Gebhart M, Scharinger A, Jangsangthong W, Busquet P, Poggiani C, Sartori S, Mangoni ME, Sinnegger-Brauns MJ and Herzig S et al.. (2011) Functional properties of a newly identified C-terminal splice variant of Cav1.3 L-type Ca2+ channels. J. Biol. Chem. 286: 42736-48 [PMID:21998310]

36. Boczek NJ, Best JM, Tester DJ, Giudicessi JR, Middha S, Evans JM, Kamp TJ and Ackerman MJ. (2013) Exome sequencing and systems biology converge to identify novel mutations in the L-type calcium channel, CACNA1C, linked to autosomal dominant long QT syndrome. Circ Cardiovasc Genet 6: 279-89 [PMID:23677916]

37. Bourinet E, Soong TW, Sutton K, Slaymaker S, Mathews E, Monteil A, Zamponi GW, Nargeot J and Snutch TP. (1999) Splicing of alpha 1A subunit gene generates phenotypic variants of P-and Q-type calcium channels. Nat. Neurosci. 2: 407-15 [PMID:10321243]

38. Bourinet E, Stotz SC, Spaetgens RL, Dayanithi G, Lemos J, Nargeot J and Zamponi GW. (2001) Interaction of SNX482 with domains III and IV inhibits activation gating of alpha(1E) $(\mathrm{Ca}(\mathrm{V}) 2.3)$ calcium channels. Biophys. J. 81: 79-88 [PMID:11423396]

39. Bowersox SS, Gadbois T, Singh T, Pettus M, Wang YX and Luther RR. (1996) Selective N-type neuronal voltage-sensitive calcium channel blocker, SNX-111, produces spinal antinociception in rat models of 
acute, persistent and neuropathic pain. J. Pharmacol. Exp. Ther. 279: 1243-9 [PMID:8968347]

40. Bowersox SS, Miljanich GP, Sugiura Y, Li C, Nadasdi L, Hoffman BB, Ramachandran J and Ko CP. (1995) Differential blockade of voltage-sensitive calcium channels at the mouse neuromuscular junction by novel omega-conopeptides and omega-agatoxin-IVA. J. Pharmacol. Exp. Ther. 273: 248-56 [PMID:7714772]

41. Boycott KM, Maybaum TA, Naylor MJ, Weleber RG, Robitaille J, Miyake Y, Bergen AA, Pierpont ME, Pearce WG and Bech-Hansen NT. (2001) A summary of 20 CACNA1F mutations identified in 36 families with incomplete $X$-linked congenital stationary night blindness, and characterization of splice variants. Hum. Genet. 108: 91-7 [PMID:11281458]

42. Boycott KM, Pearce WG and Bech-Hansen NT. (2000) Clinical variability among patients with incomplete X-linked congenital stationary night blindness and a founder mutation in CACNA1F. Can. J. Ophthalmol. 35: 204-13 [PMID:10900517]

43. Brandt A, Khimich D and Moser T. (2005) Few CaV1.3 channels regulate the exocytosis of a synaptic vesicle at the hair cell ribbon synapse. J. Neurosci. 25: 11577-85 [PMID:16354915]

44. Brandt A, Striessnig J and Moser T. (2003) CaV1.3 channels are essential for development and presynaptic activity of cochlear inner hair cells. J. Neurosci. 23: 10832-40 [PMID:14645476]

45. Brennan SC, Finney BA, Lazarou M, Rosser AE, Scherf C, Adriaensen D, Kemp PJ and Riccardi D. (2013) Fetal calcium regulates branching morphogenesis in the developing human and mouse lung: involvement of voltage-gated calcium channels. PLoS ONE 8: e80294 [PMID:24282533]

46. Brose WG, Gutlove DP, Luther RR, Bowersox SS and McGuire D. (1997) Use of intrathecal SNX-111, a novel, N-type, voltage-sensitive, calcium channel blocker, in the management of intractable brachial plexus avulsion pain. Clin J Pain 13: 256-9 [PMID:9303259]

47. Buraei Z and Yang J. (2015) Inhibition of Voltage-Gated Calcium Channels by RGK Proteins.Curr Mol Pharmacol 8: 180-7 [PMID:25966691]

48. Burashnikov E, Pfeiffer R, Barajas-Martinez H, Delpón E, Hu D, Desai M, Borggrefe M, Häissaguerre M, Kanter R and Pollevick GD et al.. (2010) Mutations in the cardiac L-type calcium channel associated with inherited J-wave syndromes and sudden cardiac death. Heart Rhythm 7: 1872-82 [PMID:20817017]

49. Burtscher V, Schicker K, Novikova E, Pöhn B, Stockner T, Kugler C, Singh A, Zeitz C, Lancelot ME and Audo I et al.. (2014) Spectrum of Cav1.4 dysfunction in congenital stationary night blindness type 2. Biochim. Biophys. Acta 1838: 2053-65 [PMID:24796500]

50. Busquet P, Nguyen NK, Schmid E, Tanimoto N, Seeliger MW, Ben-Yosef T, Mizuno F, Akopian A, Striessnig J and Singewald N. (2010) CaV1.3 L-type Ca2+ channels modulate depression-like behaviour in mice independent of deaf phenotype. Int. J. Neuropsychopharmacol. 13: 499-513 [PMID:19664321]

51. Béguin $P$, Nagashima K, Gonoi T, Shibasaki T, Takahashi K, Kashima Y, Ozaki N, Geering K, Iwanaga T and Seino S. (2001) Regulation of Ca2+ channel expression at the cell surface by the small G-protein kir/Gem. Nature 411: 701-6 [PMID:11395774]

52. Bénitah JP, Bailly P, D'Agrosa MC, Da Ponte JP, Delgado C and Lorente P. (1992) Slow inward current in single cells isolated from adult human ventricles. Pflugers Arch. 421: 176-87 [PMID:1356263]

53. Cabral MD, Paulet PE, Robert V, Gomes B, Renoud ML, Savignac M, Leclerc C, Moreau M, Lair D and Langelot $\mathrm{M}$ et al.. (2010) Knocking down Cav1 calcium channels implicated in Th2 cell activation prevents experimental asthma. Am. J. Respir. Crit. Care Med. 181: 1310-7 [PMID:20167851]

54. Caciotti A, Morrone A, Domenici R, Donati MA and Zammarchi E. (2003) Severe prognosis in a large family with hypokalemic periodic paralysis. Muscle Nerve 27: 165-9 [PMID:12548523]

55. Calin-Jageman I, Yu K, Hall RA, Mei L and Lee A. (2007) Erbin enhances voltage-dependent facilitation of $\mathrm{Ca}(\mathrm{v}) 1.3 \mathrm{Ca} 2+$ channels through relief of an autoinhibitory domain in the $\mathrm{Ca}(\mathrm{v}) 1.3$ alpha1 subunit. $J$. Neurosci. 27: 1374-85 [PMID:17287512]

56. Campiglio M, Costé de Bagneaux P, Ortner NJ, Tuluc $P$, Van Petegem F and Flucher BE. (2018) STAC proteins associate to the IQ domain of $\mathrm{Ca}_{\mathrm{V}} 1.2$ and inhibit calcium-dependent inactivation. Proc Natl Acad Sci U S A 115: 1376-1381 [PMID:29363593]

57. Cannell MB, Cheng $\mathrm{H}$ and Lederer WJ. (1995) The control of calcium release in heart muscleScience 268: 1045-9 [PMID:7754384]

58. Cao YQ and Tsien RW. (2005) Effects of familial hemiplegic migraine type 1 mutations on neuronal $P / Q-$ type Ca2+ channel activity and inhibitory synaptic transmission. Proc. Natl. Acad. Sci. U.S.A. 102: 2590-5 [PMID:15699344]

59. Carabelli V, Lovallo M, Magnelli V, Zucker H and Carbone E. (1996) Voltage-dependent modulation of single N-Type Ca2+ channel kinetics by receptor agonists in IMR32 cells. Biophys. J. 70: 2144-54 [PMID:9172738]

60. Carbone E and Lux HD. (1984) A low voltage-activated, fully inactivating Ca channel in vertebrate sensory neurones. Nature 310: 501-2 [PMID:6087159]

61. Carpenter D, Ringrose C, Leo V, Morris A, Robinson RL, Halsall PJ, Hopkins PM and Shaw MA. (2009) The role of CACNA1S in predisposition to malignant hyperthermia. BMC Med. Genet. 10: 104 [PMID:19825159]

62. Carrera P, Piatti M, Stenirri S, Grimaldi LM, Marchioni E, Curcio M, Righetti PG, Ferrari M and Gelfi C. (1999) Genetic heterogeneity in Italian families with familial hemiplegic migraine. Neurology 53: 26-33 [PMID:10408532]

63. Cassola AC, Jaffe H, Fales HM, Afeche SC, Magnoli F and Cipolla-Neto J. (1998) w-Phonetoxin-IIA: a calcium channel blocker from the spider Phoneutria nigriventer. Pflugers Arch. 436: 545-52 [PMID:9683727] 
64. Catterall WA. (2010) Ion channel voltage sensors: structure, function, and pathophysiology. Neuron 67: 915-28 [PMID:20869590]

65. Catterall WA. (2011) Voltage-gated calcium channels. Cold Spring Harb Perspect Bio/ 3: a003947 [PMID:21746798]

66. Catterall WA. (2015) Regulation of Cardiac Calcium Channels in the Fight-or-Flight Response.Curr Mol Pharmacol 8: 12-21 [PMID:25966697]

67. Catterall WA. (2000) Structure and regulation of voltage-gated Ca2+ channels.Annu. Rev. Cell Dev. Biol. 16: 521-55 [PMID:11031246]

68. Catterall WA, Perez-Reyes E, Snutch TP and Striessnig J. (2005) International Union of Pharmacology. XLVIII. Nomenclature and structure-function relationships of voltage-gated calcium channels. Pharmacol. Rev. 57: 411-25 [PMID:16382099]

69. Cavelier P, Lohof AM, Lonchamp E, Beekenkamp H, Mariani J and Bossu JL. (2008) Participation of lowthreshold Ca2+ spike in the Purkinje cells complex spike. Neuroreport 19: 299-303 [PMID:18303570]

70. Chabrier S, Monnier N and Lunardi J. (2008) Early onset of hypokalaemic periodic paralysis caused by a novel mutation of the CACNA1S gene. J. Med. Genet. 45: 686-8 [PMID:18835861]

71. Chandy KG and Gutman GA. (1993) Nomenclature for mammalian potassium channel genes. Trends Pharmacol. Sci. 14: 434 [PMID:8122319]

72. Chang B, Heckenlively JR, Bayley PR, Brecha NC, Davisson MT, Hawes NL, Hirano AA, Hurd RE, Ikeda A and Johnson BA et al.. (2006) The nob2 mouse, a null mutation in Cacna1f: anatomical and functional abnormalities in the outer retina and their consequences on ganglion cell visual responses. Vis. Neurosci. 23: 11-24 [PMID:16597347]

73. Charnet P, Bourinet E, Dubel SJ, Snutch TP and Nargeot J. (1994) Calcium currents recorded from a neuronal alpha 1C L-type calcium channel in Xenopus oocytes. FEBS Lett. 344: 87-90 [PMID:7514140]

74. Chaudhari N. (1992) A single nucleotide deletion in the skeletal muscle-specific calcium channel transcript of muscular dysgenesis (mdg) mice. J. Biol. Chem. 267: 25636-9 [PMID:1281468]

75. Chaudhuri D, Chang SY, DeMaria CD, Alvania RS, Soong TW and Yue DT. (2004) Alternative splicing as a molecular switch for $\mathrm{Ca2+/calmodulin-dependent} \mathrm{facilitation} \mathrm{of} \mathrm{P/Q-type} \mathrm{Ca2+} \mathrm{channels.} \mathrm{J.} \mathrm{Neurosci.} 24$ 6334-42 [PMID:15254089]

76. Chemin J, Monteil A, Bourinet E, Nargeot J and Lory P. (2001) Alternatively spliced alpha(1G) (Ca(V)3.1) intracellular loops promote specific T-type $\mathrm{Ca}(2+)$ channel gating properties. Biophys. J. 80: 1238-50 [PMID:11222288]

77. Chemin J, Monteil A, Dubel S, Nargeot J and Lory P. (2001) The alpha1I T-type calcium channel exhibits faster gating properties when overexpressed in neuroblastoma/glioma NG 108-15 cells. Eur. J. Neurosci. 14: 1678-86 [PMID:11860462]

78. Chemin J, Monteil A, Perez-Reyes E, Bourinet E, Nargeot J and Lory P. (2002) Specific contribution of human T-type calcium channel isotypes (alpha(1G), alpha(1H) and alpha(1I)) to neuronal excitability. J. Physiol. (Lond.) 540: 3-14 [PMID:11927664]

79. Chemin J, Monteil A, Perez-Reyes E, Nargeot J and Lory P. (2001) Direct inhibition of T-type calcium channels by the endogenous cannabinoid anandamide. EMBO J. 20: 7033-40 [PMID:11742980]

80. Chemin J, Siquier-Pernet K, Nicouleau M, Barcia G, Ahmad A, Medina-Cano D, Hanein S, Altin N, Hubert $\mathrm{L}$ and Bole-Feysot $\mathrm{C}$ et al.. (2018) De novo mutation screening in childhood-onset cerebellar atrophy identifies gain-of-function mutations in the CACNA1G calcium channel gene. Brain 141: 1998-2013 [PMID:29878067]

81. Chen CC, Lamping KG, Nuno DW, Barresi R, Prouty SJ, Lavoie JL, Cribbs LL, England SK, Sigmund CD, Weiss RM, Williamson RA, Hill JA and Campbell KP. (2003) Abnormal coronary function in mice deficient in alpha1H T-type Ca2+ channels. Science 302: 1416-8 [PMID:14631046]

82. Chen F, Liu Y, Sugiura Y, Allen PD, Gregg RG and Lin W. (2011) Neuromuscular synaptic patterning requires the function of skeletal muscle dihydropyridine receptors. Nat. Neurosci. 14: 570-7 [PMID:21441923]

83. Chen WC, Xue HZ, Hsu YL, Liu Q, Patel S and Davis RL. (2011) Complex distribution patterns of voltagegated calcium channel a-subunits in the spiral ganglion. Hear. Res. 278: 52-68 [PMID:21281707]

84. Chen Y, Lu J, Pan H, Zhang Y, Wu H, Xu K, Liu X, Jiang Y, Bao X and Yao Zt al.. (2003) Association between genetic variation of CACNA1H and childhood absence epilepsy. Ann. Neurol. 54: 239-43 [PMID:12891677]

85. Chin H, Krall M, Kim HL, Kozak CA and Mock B. (1992) The gene for the alpha 1 subunit of the skeletal muscle dihydropyridine-sensitive calcium channel (Cchl1a3) maps to mouse chromosome 1. Genomics 14: 1089-91 [PMID:1335956]

86. Chobanian AV, Bakris GL, Black HR, Cushman WC, Green LA, Izzo Jr JL, Jones DW, Materson BJ, Oparil S and Wright Jr JT et al.. (2003) Seventh report of the Joint National Committee on Prevention, Detection, Evaluation, and Treatment of High Blood Pressure. Hypertension 42: 1206-52 [PMID:14656957]

87. Choe W, Messinger RB, Leach E, Eckle VS, Obradovic A, Salajegheh R, Jevtovic-Todorovic V and Todorovic SM. (2011) TTA-P2 is a potent and selective blocker of T-type calcium channels in rat sensory neurons and a novel antinociceptive agent. Mol. Pharmacol. 80: 900-10 [PMID:21821734]

88. Choi S, Na HS, Kim J, Lee J, Lee S, Kim D, Park J, Chen CC, Campbell KP and Shin HS. (2007) Attenuated pain responses in mice lacking $\mathrm{Ca}(\mathrm{V}) 3.2$ T-type channels. Genes Brain Behav. 6: 425-31 [PMID:16939637]

89. Chuang RS, Jaffe H, Cribbs L, Perez-Reyes E and Swartz KJ. (1998) Inhibition of T-type voltage-gated calcium channels by a new scorpion toxin. Nat. Neurosci. 1: 668-74 [PMID:10196582] 
90. Clark NC, Nagano N, Kuenzi FM, Jarolimek W, Huber I, Walter D, Wietzorrek G, Boyce S, Kullmann DM and Striessnig J et al.. (2003) Neurological phenotype and synaptic function in mice lacking the CaV1.3 alpha subunit of neuronal L-type voltage-dependent Ca2+ channels. Neuroscience 120: 435-42 [PMID:12890513]

91. Coulter DA, Huguenard JR and Prince DA. (1989) Calcium currents in rat thalamocortical relay neurones: kinetic properties of the transient, low-threshold current. J. Physiol. (Lond.) 414: 587-604 [PMID:2607443]

92. Coulter DA, Huguenard JR and Prince DA. (1989) Characterization of ethosuximide reduction of lowthreshold calcium current in thalamic neurons. Ann. Neurol. 25: 582-93 [PMID:2545161]

93. Craig PJ, Beattie RE, Folly EA, Banerjee MD, Reeves MB, Priestley JV, Carney SL, Sher E, Perez-Reyes $E$ and Volsen SG. (1999) Distribution of the voltage-dependent calcium channel alpha1G subunit mRNA and protein throughout the mature rat brain. Eur. J. Neurosci. 11: 2949-64 [PMID:10457190]

94. Cribbs LL, Lee JH, Yang J, Satin J, Zhang Y, Daud A, Barclay J, Williamson MP, Fox M, Rees M and Perez-Reyes E. (1998) Cloning and characterization of alpha1 $\mathrm{H}$ from human heart, a member of the Ttype Ca2+ channel gene family. Circ. Res. 83: 103-9 [PMID:9670923]

95. Cross-Disorder Group of the Psychiatric Genomics Consortium and Genetic Risk Outcome of Psychosis (GROUP) Consortium. (2013) Identification of risk loci with shared effects on five major psychiatric disorders: a genome-wide analysis. Lancet 381: 1371-9 [PMID:23453885]

96. Cui G, Meyer AC, Calin-Jageman I, Neef J, Haeseleer F, Moser T and Lee A. (2007) Ca2+-binding proteins tune Ca2+-feedback to Cav1.3 channels in mouse auditory hair cells. J. Physiol. (Lond.) 585: 791803 [PMID:17947313]

97. Cunha SR, Hund TJ, Hashemi S, Voigt N, Li N, Wright P, Koval O, Li J, Gudmundsson H and Gumina RJ et al.. (2011) Defects in ankyrin-based membrane protein targeting pathways underlie atrial fibrillation. Circulation 124: 1212-22 [PMID:21859974]

98. D'Ascenzo M, Vairano M, Andreassi C, Navarra P, Azzena GB and Grassi C. (2004) Electrophysiological and molecular evidence of L-(Cav1), $\mathrm{N}$ - (Cav2.2), and R- (Cav2.3) type Ca2+ channels in rat cortical astrocytes. Glia 45: 354-63 [PMID:14966867]

99. Dai G, Haedo RJ, Warren VA, Ratliff KS, Bugianesi RM, Rush A, Williams ME, Herrington J, Smith MM and McManus OB et al.. (2008) A high-throughput assay for evaluating state dependence and subtype selectivity of Cav2 calcium channel inhibitors. Assay Drug Dev Technol 6: 195-212 [PMID:18471074]

100. Davare MA, Dong F, Rubin CS and Hell JW. (1999) The A-kinase anchor protein MAP2B and cAMPdependent protein kinase are associated with class C L-type calcium channels in neurons. J. Biol. Chem. 274: 30280-7 [PMID:10514522]

101. Day NC, Shaw PJ, McCormack AL, Craig PJ, Smith W, Beattie R, Williams TL, Ellis SB, Ince PG and Harpold MM et al.. (1996) Distribution of alpha $1 \mathrm{~A}$, alpha 1B and alpha $1 \mathrm{E}$ voltage-dependent calcium channel subunits in the human hippocampus and parahippocampal gyrus. Neuroscience 71: 1013-24 [PMID:8684604]

102. de Vries B, Stam AH, Beker F, van den Maagdenberg AM, Vanmolkot KR, Laan L, Ginjaar IB, Frants RR, Lauffer $\mathrm{H}$ and Haan $\mathrm{J}$ et al.. (2008) CACNA1A mutation linking hemiplegic migraine and alternating hemiplegia of childhood. Cephalalgia 28: 887-91 [PMID:18498393]

103. Denier C, Ducros A, Vahedi K, Joutel A, Thierry P, Ritz A, Castelnovo G, Deonna T, Gérard P and Devoize $\mathrm{JL}$ et al.. (1999) High prevalence of CACNA1A truncations and broader clinical spectrum in episodic ataxia type 2. Neurology 52: 1816-21 [PMID:10371528]

104. Desnuelle C, Liot D, Serratrice $G$ and Lombet A. (1985) Biochemical characterization of plasma membrane isolated from human skeletal muscle. FEBS Lett. 188: 222-6 [PMID:2411596]

105. Dick IE, Tadross MR, Liang H, Tay LH, Yang W and Yue DT. (2008) A modular switch for spatial Ca2+ selectivity in the calmodulin regulation of CaV channels. Nature 451: 830-4 [PMID:18235447]

106. Dirksen RT and Beam KG. (1995) Single calcium channel behavior in native skeletal muscle J. Gen. Physiol. 105: 227-47 [PMID:7539048]

107. Dirksen RT, Nakai J, Gonzalez A, Imoto K and Beam KG. (1997) The S5-S6 linker of repeat I is a critical determinant of L-type Ca2+ channel conductance. Biophys. J. 73: 1402-9 [PMID:9284307]

108. Doering CJ, Hamid J, Simms B, McRory JE and Zamponi GW. (2005) Cav1.4 encodes a calcium channel with low open probability and unitary conductance. Biophys. J. 89: 3042-8 [PMID:16085774]

109. Doering CJ, Rehak R, Bonfield S, Peloquin JB, Stell WK, Mema SC, Sauvé Y and McRory JE. (2008) Modified $\mathrm{Ca}(\mathrm{v}) 1.4$ expression in the Cacna1f(nob2) mouse due to alternative splicing of an ETn inserted in exon 2. PLOS ONE 3: e2538 [PMID:18596967]

110. Dogrul A, Gardell LR, Ossipov MH, Tulunay FC, Lai J and Porreca F. (2003) Reversal of experimental neuropathic pain by T-type calcium channel blockers. Pain 105: 159-68 [PMID:14499432]

111. Domes K, Ding J, Lemke T, Blaich A, Wegener JW, Brandmayr J, Moosmang S and Hofmann F. (2011) Truncation of murine CaV1.2 at Asp-1904 results in heart failure after birth. J. Biol. Chem. 286: 33863-71 [PMID:21832054]

112. Dos Santos RG, Van Renterghem C, Martin-Moutot N, Mansuelle P, Cordeiro MN, Diniz CR, Mori Y, De Lima ME and Seagar M. (2002) Phoneutria nigriventer omega-phonetoxin IIA blocks the Cav2 family of calcium channels and interacts with omega-conotoxin-binding sites. J. Biol. Chem. 277: 13856-62 [PMID:11827974]

113. Dove LS, Abbott LC and Griffith WH. (1998) Whole-cell and single-channel analysis of P-type calcium currents in cerebellar Purkinje cells of leaner mutant mice. J. Neurosci. 18: 7687-99 [PMID:9742139]

114. Drouet B, Garcia L, Simon-Chazottes D, Mattei MG, Guénet JL, Schwartz A, Varadi G and Pinçon- 
Raymond M. (1993) The gene coding for the alpha 1 subunit of the skeletal dihydropyridine receptor $($ Cchl1a3 $=$ mdg) maps to mouse chromosome 1 and human 1q32. Mamm. Genome 4: 499-503 [PMID:8118099]

115. Dubel SJ, Starr TV, Hell J, Ahlijanian MK, Enyeart JJ, Catterall WA and Snutch TP. (1992) Molecular cloning of the alpha-1 subunit of an omega-conotoxin-sensitive calcium channel. Proc. Natl. Acad. Sci. U.S.A. 89: 5058-62 [PMID:1317580]

116. Ducros A, Denier C, Joutel A, Cecillon M, Lescoat C, Vahedi K, Darcel F, Vicaut E, Bousser MG and Tournier-Lasserve E. (2001) The clinical spectrum of familial hemiplegic migraine associated with mutations in a neuronal calcium channel. N. Engl. J. Med. 345: 17-24 [PMID:11439943]

117. Ducros A, Denier C, Joutel A, Vahedi K, Michel A, Darcel F, Madigand M, Guerouaou D, Tison F and Julien J et al.. (1999) Recurrence of the T666M calcium channel CACNA1A gene mutation in familial hemiplegic migraine with progressive cerebellar ataxia. Am. J. Hum. Genet. 64: 89-98 [PMID:9915947]

118. Ellis SB, Williams ME, Ways NR, Brenner R, Sharp AH, Leung AT, Campbell KP, McKenna E, Koch WJ and Hui A. (1988) Sequence and expression of mRNAs encoding the alpha 1 and alpha 2 subunits of a DHP-sensitive calcium channel. Science 241: 1661-4 [PMID:2458626]

119. Emerick MC, Stein R, Kunze R, McNulty MM, Regan MR, Hanck DA and Agnew WS. (2006) Profiling the array of $\mathrm{Ca}(\mathrm{v}) 3.1$ variants from the human T-type calcium channel gene CACNA1G: alternative structures, developmental expression, and biophysical variations. Proteins 64: 320-42 [PMID:16671074]

120. Ertel EA, Campbell KP, Harpold MM, Hofmann F, Mori Y, Perez-Reyes E, Schwartz A, Snutch TP, Tanabe T, Birnbaumer L, Tsien RW and Catterall WA. (2000) Nomenclature of voltage-gated calcium channels. Neuron 25: 533-5 [PMID:10774722]

121. Fan C, Lehmann-Horn F, Weber MA, Bednarz M, Groome JR, Jonsson MK and Jurkat-Rott K. (2013) Transient compartment-like syndrome and normokalaemic periodic paralysis due to a Cav1.1 mutation. Brain 136: 3775-86 [PMID:24240197]

122. Feng ZP, Hamid J, Doering C, Jarvis SE, Bosey GM, Bourinet E, Snutch TP and Zamponi GW. (2001) Amino acid residues outside of the pore region contribute to $\mathrm{N}$-type calcium channel permeation. J. Biol. Chem. 276: 5726-30 [PMID:11120735]

123. Ferron L, Kadurin I and Dolphin AC. (2018) Proteolytic maturation of $\alpha_{2} \delta$ controls the probability of synaptic vesicular release. Elife 7: [PMID:29916807]

124. Flucher BE. (2020) Skeletal muscle Ca11.1 channelopathies. Pflugers Arch 472: 739-754 [PMID:32222817]

125. Flucher BE, Andrews SB, Fleischer S, Marks AR, Caswell A and Powell JA. (1993) Triad formation: organization and function of the sarcoplasmic reticulum calcium release channel and triadin in normal and dysgenic muscle in vitro. J. Cell Biol. 123: 1161-74 [PMID:8245124]

126. Flucher BE and Campiglio M. (2019) STAC proteins: The missing link in skeletal muscle EC coupling and new regulators of calcium channel function. Biochim Biophys Acta Mol Cell Res 1866: 1101-1110 [PMID:30543836]

127. Flucher BE and Tuluc P. (2011) A new L-type calcium channel isoform required for normal patterning of the developing neuromuscular junction. Channels (Austin) 5: 518-24 [PMID:21993196]

128. Foell JD, Balijepalli RC, Delisle BP, Yunker AM, Robia SL, Walker JW, McEnery MW, January CT and Kamp TJ. (2004) Molecular heterogeneity of calcium channel beta-subunits in canine and human heart: evidence for differential subcellular localization. Physiol. Genomics 17: 183-200 [PMID:14762176]

129. Forti L, Tottene A, Moretti A and Pietrobon D. (1994) Three novel types of voltage-dependent calcium channels in rat cerebellar neurons. J. Neurosci. 14: 5243-56 [PMID:8083734]

130. Fouad G, Dalakas M, Servidei S, Mendell JR, Van den Bergh P, Angelini C, Alderson K, Griggs RC, Tawil $\mathrm{R}$ and Gregg $\mathrm{R}$ et al.. (1997) Genotype-phenotype correlations of DHP receptor alpha 1-subunit gene mutations causing hypokalemic periodic paralysis. Neuromuscul. Disord. 7: 33-8 [PMID:9132138]

131. Fowler MR, Colotti G, Chiancone E, Smith GL and Fearon IM. (2008) Sorcin modulates cardiac L-type $\mathrm{Ca2}+$ current by functional interaction with the alpha1C subunit in rabbits. Exp. Physiol. 93: 1233-8 [PMID:18603601]

132. Francois A, Kerckhove N, Meleine M, Alloui A, Barrere C, Gelot A, Uebele VN, Renger JJ, Eschalier A and Ardid D et al.. (2013) State-dependent properties of a new T-type calcium channel blocker enhance $\mathrm{Ca}(\mathrm{V}) 3.2$ selectivity and support analgesic effects. Pain 154: 283-93 [PMID:23257507]

133. Freise D, Held B, Wissenbach U, Pfeifer A, Trost C, Himmerkus N, Schweig U, Freichel M, Biel M and Hofmann $\mathrm{F}$ et al.. (2000) Absence of the gamma subunit of the skeletal muscle dihydropyridine receptor increases L-type Ca2+ currents and alters channel inactivation properties. J. Biol. Chem. 275: 14476-81 [PMID:10799530]

134. Friend KL, Crimmins D, Phan TG, Sue CM, Colley A, Fung VS, Morris JG, Sutherland GR and Richards RI. (1999) Detection of a novel missense mutation and second recurrent mutation in the CACNA1A gene in individuals with EA-2 and FHM. Hum. Genet. 105: 261-5 [PMID:10987655]

135. Fu Y, Westenbroek RE, Scheuer T and Catterall WA. (2013) Phosphorylation sites required for regulation of cardiac calcium channels in the fight-or-flight response. Proc. Natl. Acad. Sci. U.S.A. 110: 19621-6 [PMID:24218620]

136. Fu Y, Westenbroek RE, Yu FH, Clark 3rd JP, Marshall MR, Scheuer T and Catterall WA. (2011) Deletion of the distal $\mathrm{C}$ terminus of $\mathrm{CaV} 1.2$ channels leads to loss of beta-adrenergic regulation and heart failure in vivo. J. Biol. Chem. 286: 12617-26 [PMID:21216955]

137. Fujii S, Kameyama K, Hosono M, Hayashi Y and Kitamura K. (1997) Effect of cilnidipine, a novel 
dihydropyridine $\mathrm{Ca++-channel} \mathrm{antagonist,} \mathrm{on} \mathrm{N}$-type $\mathrm{Ca++}$ channel in rat dorsal root ganglion neurons. J. Pharmacol. Exp. Ther. 280: 1184-91 [PMID:9067302]

138. Fukuyama M, Ohno S, Wang Q, Kimura H, Makiyama T, Itoh H, Ito M and Horie M. (2013) L-type calcium channel mutations in Japanese patients with inherited arrhythmias. Circ. J. 77: 1799-806 [PMID:23575362]

139. Furukawa T, Miura R, Honda M, Kamiya N, Mori Y, Takeshita S, Isshiki T and Nukada T. (2004) Identification of $\mathrm{R}(-)$-isomer of efonidipine as a selective blocker of T-type Ca2+ channels. Br. J. Pharmacol. 143: 1050-7 [PMID:15545287]

140. Gardner K, BernalO, Keegan M, Badger J, Gerber O, Lowry N and Hoffman EP. (1999) A new mutation in the Chr19p calcium channel gene CACNLIA4 causing hemiplegic migraine with ataxia. Neurology 52: A115

141. Gebhart M, Juhasz-Vedres G, Zuccotti A, Brandt N, Engel J, Trockenbacher A, Kaur G, Obermair GJ, Knipper M and Koschak A et al.. (2010) Modulation of Cav1.3 Ca2+ channel gating by Rab3 interacting molecule. Mol. Cell. Neurosci. 44: 246-59 [PMID:20363327]

142. Ghasemzadeh MB, Pierce RC and Kalivas PW. (1999) The monoamine neurons of the rat brain preferentially express a splice variant of alpha1B subunit of the $\mathrm{N}$-type calcium channel. J. Neurochem. 73: 1718-23 [PMID:10501220]

143. Giffin NJ, Benton S and Goadsby PJ. (2002) Benign paroxysmal torticollis of infancy: four new cases and linkage to CACNA1A mutation. Dev Med Child Neurol44: 490-3 [PMID:12162387]

144. Gillis J, Burashnikov E, Antzelevitch C, Blaser S, Gross G, Turner L, Babul-Hirji R and Chitayat D. (2012) Long QT, syndactyly, joint contractures, stroke and novel CACNA1C mutation: expanding the spectrum of Timothy syndrome. Am. J. Med. Genet. A158A: 182-7 [PMID:22106044]

145. Giordanetto $F$, Knerr $L$ and Wållberg A. (2011) T-type calcium channels inhibitors: a patent review Expert Opin Ther Pat 21: 85-101 [PMID:21087200]

146. Giordano TP, Tropea TF, Satpute SS, Sinnegger-Brauns MJ, Striessnig J, Kosofsky BE and Rajadhyaksha AM. (2010) Molecular switch from L-type Ca v 1.3 to Ca v 1.2 Ca2+ channel signaling underlies long-term psychostimulant-induced behavioral and molecular plasticity. J. Neurosci. 30: 17051 62 [PMID:21159975]

147. Glossmann H and Striessnig J. (1990) Molecular properties of calcium channels.Rev. Physiol. Biochem. Pharmacol. 114: 1-105 [PMID:2155469]

148. Goll A, Ferry DR, Striessnig J, Schober M and Glossmann H. (1984) (-)-[3H]Desmethoxyverapamil, a novel $\mathrm{Ca} 2+$ channel probe. Binding characteristics and target size analysis of its receptor in skeletal muscle. FEBS Lett. 176: 371-7 [PMID:6092142]

149. Gomora JC, Daud AN, Weiergräber M and Perez-Reyes E. (2001) Block of cloned human T-type calcium channels by succinimide antiepileptic drugs. Mol. Pharmacol. 60: 1121-32 [PMID:11641441]

150. Gomora JC, Murbartián J, Arias JM, Lee JH and Perez-Reyes E. (2002) Cloning and expression of the human T-type channel $\mathrm{Ca}(\mathrm{v}) 3.3$ : insights into prepulse facilitation. Biophys. J. 83: 229-41 [PMID:12080115]

151. Goonasekera SA, Hammer K, Auger-Messier M, Bodi I, Chen X, Zhang H, Reiken S, Elrod JW, Correll RN and York AJ et al.. (2012) Decreased cardiac L-type $\mathrm{Ca}^{{ }^{+}}$channel activity induces hypertrophy and heart failure in mice. J. Clin. Invest. 122: 280-90 [PMID:22133878]

152. Grant $L$ and Fuchs $P$. (2008) Calcium- and calmodulin-dependent inactivation of calcium channels in inner hair cells of the rat cochlea. J. Neurophysiol. 99: 2183-93 [PMID:18322004]

153. Graves TD, Imbrici P, Kors EE, Terwindt GM, Eunson LH, Frants RR, Haan J, Ferrari MD, Goadsby PJ and Hanna MG et al.. (2008) Premature stop codons in a facilitating EF-hand splice variant of CaV2.1 cause episodic ataxia type 2. Neurobiol. Dis. 32: 10-5 [PMID:18606230]

154. Gregory FD, Bryan KE, Pangršič T, Calin-Jageman IE, Moser T and Lee A. (2011) Harmonin inhibits presynaptic Cav1.3 $\mathrm{Ca}^{2+}$ channels in mouse inner hair cells. Nat. Neurosci. 14: 1109-11 [PMID:21822269]

155. Gregory FD, Pangrsic T, Calin-Jageman IE, Moser T and Lee A. (2013) Harmonin enhances voltagedependent facilitation of Cav1.3 channels and synchronous exocytosis in mouse inner hair cells. J. Physiol. (Lond.) 591: 3253-69 [PMID:23613530]

156. Griessmeier K, Cuny H, Rötzer K, Griesbeck O, Harz H, Biel M and Wahl-Schott C. (2009) Calmodulin is a functional regulator of Cav1.4 L-type Ca2+ channels. J. Biol. Chem. 284: 29809-16 [PMID:19717559]

157. Guida S, Trettel F, Pagnutti S, Mantuano E, Tottene A, Veneziano L, Fellin T, Spadaro M, Stauderman K and Williams $M$ et al.. (2001) Complete loss of $P / Q$ calcium channel activity caused by a CACNA1A missense mutation carried by patients with episodic ataxia type 2. Am. J. Hum. Genet. 68: 759-64 [PMID:11179022]

158. Gundlfinger A, Bischofberger J, Johenning FW, Torvinen M, Schmitz D and Breustedt J. (2007) Adenosine modulates transmission at the hippocampal mossy fibre synapse via direct inhibition of presynaptic calcium channels. J. Physiol. (Lond.) 582: 263-77 [PMID:17478533]

159. Gómez AM, Valdivia HH, Cheng H, Lederer MR, Santana LF, Cannell MB, McCune SA, Altschuld RA and Lederer WJ. (1997) Defective excitation-contraction coupling in experimental cardiac hypertrophy and heart failure. Science 276: 800-6 [PMID:9115206]

160. Haase H, Kresse A, Hohaus A, Schulte HD, Maier M, Osterziel KJ, Lange PE and Morano I. (1996) Expression of calcium channel subunits in the normal and diseased human myocardium. J. Mol. Med. 74: 99-104 [PMID:8820405]

161. Haeseleer F, Imanishi Y, Maeda T, Possin DE, Maeda A, Lee A, Rieke F and Palczewski K. (2004) Essential role of Ca2+-binding protein 4, a Cav1.4 channel regulator, in photoreceptor synaptic function. Nat. Neurosci. 7: 1079-87 [PMID:15452577]

162. Hagiwara M, Adachi-Akahane S and Nagao T. (1997) High-affinity binding of DTZ323, a novel derivative 
of diltiazem, to rabbit skeletal muscle L-type Ca++ channels. J. Pharmacol. Exp. Ther. 281: 173-9 [PMID:9103495]

163. Hall DD, Dai S, Tseng PY, Malik Z, Nguyen M, Matt L, Schnizler K, Shephard A, Mohapatra DP and Tsuruta $\mathrm{F}$ et al.. (2013) Competition between $\alpha$-actinin and $\mathrm{Ca}^{2+}$-calmodulin controls surface retention of the L-type $\mathrm{Ca}^{2+}$ channel $\mathrm{Ca}(\mathrm{V}) 1.2$. Neuron 78: 483-97 [PMID:23664615]

164. Hall DD, Feekes JA, Arachchige Don AS, Shi M, Hamid J, Chen L, Strack S, Zamponi GW, Horne MC and Hell JW. (2006) Binding of protein phosphatase 2A to the L-type calcium channel Cav1.2 next to Ser1928, its main PKA site, is critical for Ser1928 dephosphorylation. Biochemistry 45: 3448-59 [PMID:16519540]

165. Han W, Saegusa H, Zong S and Tanabe T. (2002) Altered cocaine effects in mice lacking Ca(v)2.3 (alpha(1E)) calcium channel. Biochem. Biophys. Res. Commun. 299: 299-304 [PMID:12437986]

166. Han Y, Kaeser PS, Südhof TC and Schneggenburger R. (2011) RIM determines $\mathrm{Ca}^{2}+$ channel density and vesicle docking at the presynaptic active zone. Neuron 69: 304-16 [PMID:21262468]

167. Hans M, Luvisetto S, Williams ME, Spagnolo M, Urrutia A, Tottene A, Brust PF, Johnson EC, Harpold MM and Stauderman KA et al.. (1999) Functional consequences of mutations in the human alpha1A calcium channel subunit linked to familial hemiplegic migraine. J. Neurosci. 19: 1610-9 [PMID:10024348]

168. Hans M, Urrutia A, Deal C, Brust PF, Stauderman K, Ellis SB, Harpold MM, Johnson EC and Williams ME. (1999) Structural elements in domain IV that influence biophysical and pharmacological properties of human alpha1A-containing high-voltage-activated calcium channels. Biophys. J. 76: 1384-400 [PMID:10049321]

169. Hansen PB, Jensen BL, Andreasen D, Friis UG and Skøtt O. (2000) Vascular smooth muscle cells express the alpha(1A) subunit of a P-/Q-type voltage-dependent $\mathrm{Ca}(2+)$ Channel, and It is functionally important in renal afferent arterioles. Circ. Res. 87: 896-902 [PMID:11073885]

170. Hauke J, Schild A, Neugebauer A, Lappa A, Fricke J, Fauser S, Rösler S, Pannes A, Zarrinnam D and Altmüller J et al.. (2013) A novel large in-frame deletion within the CACNA1F gene associates with a conerod dystrophy 3-like phenotype. PLoS ONE 8: e76414 [PMID:24124559]

171. Hawrylycz MJ, Lein ES, Guillozet-Bongaarts AL, Shen EH, Ng L, Miller JA, van de Lagemaat LN, Smith KA, Ebbert A and Riley ZL et al.. (2012) An anatomically comprehensive atlas of the adult human brain transcriptome. Nature 489: 391-9 [PMID:22996553]

172. Heady TN, Gomora JC, Macdonald TL and Perez-Reyes E. (2001) Molecular pharmacology of T-type Ca2+ channels. Jpn. J. Pharmacol. 85: 339-50 [PMID:11388636]

173. Heinemann SH, Terlau H, Stühmer W, Imoto K and Numa S. (1992) Calcium channel characteristics conferred on the sodium channel by single mutations. Nature 356: 441-3 [PMID:1313551]

174. Helbig KL, Lauerer RJ, Bahr JC, Souza IA, Myers CT, Uysal B, Schwarz N, Gandini MA, Huang S and Keren B et al.. (2018) De Novo Pathogenic Variants in CACNA1E Cause Developmental and Epileptic Encephalopathy with Contractures, Macrocephaly, and Dyskinesias. Am J Hum Genet 103: 666-678 [PMID:30343943]

175. Helton TD, Xu W and Lipscombe D. (2005) Neuronal L-type calcium channels open quickly and are inhibited slowly. J. Neurosci. 25: 10247-51 [PMID:16267232]

176. Hemara-Wahanui A, Berjukow S, Hope CI, Dearden PK, Wu SB, Wilson-Wheeler J, Sharp DM, LundonTreweek P, Clover GM and Hoda JC et al.. (2005) A CACNA1F mutation identified in an X-linked retinal disorder shifts the voltage dependence of Cav1.4 channel activation. Proc. Natl. Acad. Sci. U.S.A. 102: 7553-8 [PMID:15897456]

177. Heron SE, Phillips HA, Mulley JC, Mazarib A, Neufeld MY, Berkovic SF and Scheffer IE. (2004) Genetic variation of CACNA1H in idiopathic generalized epilepsy. Ann. Neurol. 55: 595-6 [PMID:15048902]

178. Hess $P$, Lansman JB and Tsien RW. (1986) Calcium channel selectivity for divalent and monovalent cations. Voltage and concentration dependence of single channel current in ventricular heart cells. J. Gen. Physiol. 88: 293-319 [PMID:2428919]

179. Hibino H, Pironkova R, Onwumere O, Rousset M, Charnet P, Hudspeth AJ and Lesage F. (2003) Direct interaction with a nuclear protein and regulation of gene silencing by a variant of the Ca2+-channel beta 4 subunit. Proc. Natl. Acad. Sci. U.S.A. 100: 307-12 [PMID:12518067]

180. Hillyard DR, Monje VD, Mintz IM, Bean BP, Nadasdi L, Ramachandran J, Miljanich G, Azimi-Zoonooz A, Mclntosh JM and Cruz LJ. (1992) A new Conus peptide ligand for mammalian presynaptic Ca2+ channels. Neuron 9: 69-77 [PMID:1352986]

181. Hirano M, Kokunai Y, Nagai A, Nakamura Y, Saigoh K, Kusunoki S and Takahashi MP. (2011) A novel mutation in the calcium channel gene in a family with hypokalemic periodic paralysis. J. Neurol. Sci. 309: 911 [PMID:21855088]

182. Hirtz JJ, Braun N, Griesemer D, Hannes C, Janz K, Löhrke S, Müller B and Friauf E. (2012) Synaptic refinement of an inhibitory topographic map in the auditory brainstem requires functional Cav1.3 calcium channels. J. Neurosci. 32: 14602-16 [PMID:23077046]

183. Hobai IA, Bates JA, Howarth FC and Levi AJ. (1997) Inhibition by external Cd2+ of Na/Ca exchange and L-type Ca channel in rabbit ventricular myocytes. Am. J. Physiol. 272: H2164-72 [PMID:9176282]

184. Hockerman GH, Johnson BD, Scheuer T and Catterall WA. (1995) Molecular determinants of high affinity phenylalkylamine block of L-type calcium channels. J. Biol. Chem. 270: 22119-22 [PMID:7673189]

185. Hockerman GH, Peterson BZ, Johnson BD and Catterall WA. (1997) Molecular determinants of drug binding and action on L-type calcium channels. Annu. Rev. Pharmacol. Toxicol. 37: 361-96 [PMID:9131258]

186. Hoda JC, Zaghetto F, Koschak A and Striessnig J. (2005) Congenital stationary night blindness type 2 
mutations S229P, G369D, L1068P, and W1440X alter channel gating or functional expression of Ca(v)1.4 L-type Ca2+ channels. J. Neurosci. 25: 252-9 [PMID:15634789]

187. Hoda JC, Zaghetto F, Singh A, Koschak A and Striessnig J. (2006) Effects of congenital stationary night blindness type 2 mutations R508Q and L1364H on Cav1.4 L-type Ca2+ channel function and expression. J. Neurochem. 96: 1648-58 [PMID:16476079]

188. Hofmann F, Lacinová L and Klugbauer N. (1999) Voltage-dependent calcium channels: from structure to function. Rev. Physiol. Biochem. Pharmacol. 139: 33-87 [PMID:10453692]

189. Holmkvist J, Tojjar D, Almgren P, Lyssenko V, Lindgren CM, Isomaa B, Tuomi T, Berglund G, Renström E and Groop L. (2007) Polymorphisms in the gene encoding the voltage-dependent $\mathrm{Ca}(2+)$ channel $\mathrm{Ca}$ (V)2.3 (CACNA1E) are associated with type 2 diabetes and impaired insulin secretion. Diabetologia 50: 2467-75 [PMID:17934712]

190. Hong TT, Smyth JW, Gao D, Chu KY, Vogan JM, Fong TS, Jensen BC, Colecraft HM and Shaw RM. (2010) BIN1 localizes the L-type calcium channel to cardiac T-tubules. PLoS Biol. 8: e1000312 [PMID:20169111]

191. Horstick EJ, Linsley JW, Dowling JJ, Hauser MA, McDonald KK, Ashley-Koch A, Saint-Amant L, Satish A, Cui WW and Zhou W et al.. (2013) Stac3 is a component of the excitation-contraction coupling machinery and mutated in Native American myopathy. Nat Commun 4: 1952 [PMID:23736855]

192. Huang H, Yu D and Soong TW. (2013) C-terminal alternative splicing of CaV1.3 channels distinctively modulates their dihydropyridine sensitivity. Mol. Pharmacol. 84: 643-53 [PMID:23924992]

193. Huguenard JR, Gutnick MJ and Prince DA. (1993) Transient Ca2+ currents in neurons isolated from rat lateral habenula. J. Neurophysiol. 70: 158-66 [PMID:8395572]

194. Hulme JT, Ahn M, Hauschka SD, Scheuer T and Catterall WA. (2002) A novel leucine zipper targets AKAP15 and cyclic AMP-dependent protein kinase to the $C$ terminus of the skeletal muscle Ca2+ channel and modulates its function. J. Biol. Chem. 277: 4079-87 [PMID:11733497]

195. Ihara Y, Yamada Y, Fujii Y, Gonoi T, Yano H, Yasuda K, Inagaki N, Seino Y and Seino S. (1995) Molecular diversity and functional characterization of voltage-dependent calcium channels (CACN4) expressed in pancreatic beta-cells. Mol. Endocrinol. 9: 121-30 [PMID:7760845]

196. Imbrici P, Jaffe SL, Eunson LH, Davies NP, Herd C, Robertson R, Kullmann DM and Hanna MG. (2004) Dysfunction of the brain calcium channel CaV2.1 in absence epilepsy and episodic ataxia. Brain 127: 2682-92 [PMID:15483044]

197. Ino M, Yoshinaga T, Wakamori M, Miyamoto N, Takahashi E, Sonoda J, Kagaya T, Oki T, Nagasu T and Nishizawa $Y$ et al.. (2001) Functional disorders of the sympathetic nervous system in mice lacking the alpha 1B subunit (Cav 2.2) of N-type calcium channels. Proc. Natl. Acad. Sci. U.S.A. 98: 5323-8 [PMID:11296258]

198. Ishikawa K, Fujigasaki H, Saegusa H, Ohwada K, Fujita T, Iwamoto H, Komatsuzaki Y, Toru S, Toriyama $\mathrm{H}$ and Watanabe $\mathrm{M}$ et al.. (1999) Abundant expression and cytoplasmic aggregations of [alpha]1A voltagedependent calcium channel protein associated with neurodegeneration in spinocerebellar ataxia type 6. Hum. Mol. Genet. 8: 1185-93 [PMID:10369863]

199. Jalkanen R, Bech-Hansen NT, Tobias R, Sankila EM, Mäntyjärvi M, Forsius H, de la Chapelle A and Alitalo T. (2007) A novel CACNA1F gene mutation causes Aland Island eye disease. Invest. Ophthalmol. Vis. Sci. 48: 2498-502 [PMID:17525176]

200. Jalkanen R, Mäntyjärvi M, Tobias R, Isosomppi J, Sankila EM, Alitalo T and Bech-Hansen NT. (2006) X linked cone-rod dystrophy, CORDX3, is caused by a mutation in the CACNA1F gene. J. Med. Genet. 43: 699-704 [PMID:16505158]

201. Jarvis MF, Scott VE, McGaraughty S, Chu KL, Xu J, Niforatos W, Milicic I, Joshi S, Zhang Q and Xia Z. (2014) A peripherally acting, selective T-type calcium channel blocker, ABT-639, effectively reduces nociceptive and neuropathic pain in rats. Biochem. Pharmacol. 89: 536-44 [PMID:24726441]

202. Jay SD, Ellis SB, McCue AF, Williams ME, Vedvick TS, Harpold MM and Campbell KP. (1990) Primary structure of the gamma subunit of the DHP-sensitive calcium channel from skeletal muscle. Science 248: 490-2 [PMID:2158672]

203. Jen J, Kim GW and Baloh RW. (2004) Clinical spectrum of episodic ataxia type 2.Neurology 62: 17-22 [PMID:14718690]

204. Jen J, Wan J, Graves M, Yu H, Mock AF, Coulin CJ, Kim G, Yue Q, Papazian DM and Baloh RW. (2001) Loss-of-function EA2 mutations are associated with impaired neuromuscular transmission. Neurology 57: 1843-8 [PMID:11723274]

205. Jen J, Yue Q, Nelson SF, Yu H, Litt M, Nutt J and Baloh RW. (1999) A novel nonsense mutation in CACNA1A causes episodic ataxia and hemiplegia. Neurology 53: 34-7 [PMID:10408533]

206. Jeng CJ, Chen YT, Chen YW and Tang CY. (2006) Dominant-negative effects of human P/Q-type Ca2+ channel mutations associated with episodic ataxia type 2. Am. J. Physiol., Cell Physiol.290: C1209-20 [PMID:16306128]

207. Jenkins MA, Christel CJ, Jiao Y, Abiria S, Kim KY, Usachev YM, Obermair GJ, Colbran RJ and Lee A (2010) Ca2+-dependent facilitation of Cav1.3 Ca2+ channels by densin and Ca2+/calmodulin-dependent protein kinase II. J. Neurosci. 30: 5125-35 [PMID:20392935]

208. Jeon D, Kim C, Yang YM, Rhim H, Yim E, Oh U and Shin HS. (2007) Impaired long-term memory and long-term potentiation in N-type Ca2+ channel-deficient mice. Genes Brain Behav. 6: 375-88 [PMID:16939638]

209. Jeon D, Kim S, Chetana M, Jo D, Ruley HE, Lin SY, Rabah D, Kinet JP and Shin HS. (2010) Observational fear learning involves affective pain system and Cav1.2 Ca2+ channels in ACC. Nat. Neurosci. 13: 482-8 
[PMID:20190743]

210. Jiménez C, Bourinet E, Leuranguer V, Richard S, Snutch TP and Nargeot J. (2000) Determinants of voltage-dependent inactivation affect Mibefradil block of calcium channels. Neuropharmacology 39: 1-10 [PMID:10665814]

211. Jing X, Li DQ, Olofsson CS, Salehi A, Surve VV, Caballero J, Ivarsson R, Lundquist I, Pereverzev A and Schneider T et al.. (2005) CaV2.3 calcium channels control second-phase insulin release.J. Clin. Invest. 115: 146-54 [PMID:15630454]

212. Johnson BD, Hockerman GH, Scheuer T and Catterall WA. (1996) Distinct effects of mutations in transmembrane segment IVS6 on block of L-type calcium channels by structurally similar phenylalkylamines. Mol. Pharmacol. 50: 1388-400 [PMID:8913371]

213. Jouvenceau A, Eunson LH, Spauschus A, Ramesh V, Zuberi SM, Kullmann DM and Hanna MG. (2001) Human epilepsy associated with dysfunction of the brain P/Q-type calcium channel. Lancet 358: 801-7 [PMID:11564488]

214. Jurkat-Rott K, Lehmann-Horn F, Elbaz A, Heine R, Gregg RG, Hogan K, Powers PA, Lapie P, ValeSantos JE and Weissenbach J et al.. (1994) A calcium channel mutation causing hypokalemic periodic paralysis. Hum. Mol. Genet. 3: 1415-9 [PMID:7987325]

215. Jurkat-Rott K, Lerche H and Lehmann-Horn F. (2002) Skeletal muscle channelopathies.J. Neurol. 249: 1493-502 [PMID:12420087]

216. Jurkat-Rott K, Weber MA, Fauler M, Guo XH, Holzherr BD, Paczulla A, Nordsborg N, Joechle W and Lehmann-Horn F. (2009) K+-dependent paradoxical membrane depolarization and $\mathrm{Na}+$ overload, major and reversible contributors to weakness by ion channel leaks. Proc. Natl. Acad. Sci. U.S.A. 106: 4036-41 [PMID:19225109]

217. Kaeser PS, Deng L, Wang Y, Dulubova I, Liu X, Rizo J and Südhof TC. (2011) RIM proteins tether Ca2+ channels to presynaptic active zones via a direct PDZ-domain interaction. Cell 144: 282-95 [PMID:21241895]

218. Kaja S, van de Ven RC, Broos LA, Veldman H, van Dijk JG, Verschuuren JJ, Frants RR, Ferrari MD, van den Maagdenberg AM and Plomp JJ. (2005) Gene dosage-dependent transmitter release changes at neuromuscular synapses of CACNA1A R192Q knockin mice are non-progressive and do not lead to morphological changes or muscle weakness. Neuroscience 135: 81-95 [PMID:16111830]

219. Kanaya S and Katzung BG. (1984) Effects of diltiazem on transmembrane potential and current of right ventricular papillary muscle of ferrets. J Pharmacol Exp Ther 228: 245-51 [PMID:6694106]

220. Kaneko S, Cooper CB, Nishioka N, Yamasaki H, Suzuki A, Jarvis SE, Akaike A, Satoh M and Zamponi GW. (2002) Identification and characterization of novel human Ca(v)2.2 (alpha 1B) calcium channel variants lacking the synaptic protein interaction site. J. Neurosci. 22: 82-92 [PMID:11756491]

221. Kawabata M, Ogawa T, Han WH and Takabatake T. (1999) Renal effects of efonidipine hydrochloride, a new calcium antagonist, in spontaneously hypertensive rats with glomerular injury. Clin. Exp. Pharmacol. Physiol. 26: 674-9 [PMID:10499155]

222. Ke T, Gomez CR, Mateus HE, Castano JA and Wang QK. (2009) Novel CACNA1S mutation causes autosomal dominant hypokalemic periodic paralysis in a South American family. J. Hum. Genet. 54: 660-4 [PMID:19779499]

223. Kersten FF, van Wijk E, van Reeuwijk J, van der Zwaag B, Märker T, Peters TA, Katsanis N, Wolfrum U, Keunen JE and Roepman R et al.. (2010) Association of whirlin with Cav1.3 (alpha1D) channels in photoreceptors, defining a novel member of the usher protein network. Invest. Ophthalmol. Vis. Sci. 51: 2338-46 [PMID:19959638]

224. Khosravani H, Bladen C, Parker DB, Snutch TP, McRory JE and Zamponi GW. (2005) Effects of Cav3.2 channel mutations linked to idiopathic generalized epilepsy. Ann. Neurol. 57: 745-9 [PMID:15852375]

225. Kim C, Jun K, Lee T, Kim SS, McEnery MW, Chin H, Kim HL, Park JM, Kim DK and Jung SJet al.. (2001) Altered nociceptive response in mice deficient in the alpha(1B) subunit of the voltage-dependent calcium channel. Mol. Cell. Neurosci. 18: 235-45 [PMID:11520183]

226. Kim D, Song I, Keum S, Lee T, Jeong MJ, Kim SS, McEnery MW and Shin HS. (2001) Lack of the burst firing of thalamocortical relay neurons and resistance to absence seizures in mice lacking alpha(1G) Ttype $\mathrm{Ca}(2+)$ channels. Neuron 31: 35-45 [PMID:11498049]

227. Kim S, Yun HM, Baik JH, Chung KC, Nah SY and Rhim H. (2007) Functional interaction of neuronal Cav1.3 L-type calcium channel with ryanodine receptor type 2 in the rat hippocampus. J. Biol. Chem. 282: 32877-89 [PMID:17823125]

228. Kimm T and Bean BP. (2014) Inhibition of A-type potassium current by the peptide toxin SNX-482J. Neurosci. 34: 9182-9 [PMID:25009251]

229. Kipfer S, Jung S, Lemke JR, Kipfer-Kauer A, Howell JP, Kaelin-Lang A, Nyffeler T, Gutbrod K, Abicht A and Müri RM. (2013) Novel CACNA1A mutation(s) associated with slow saccade velocities. J. Neurol. 260: 3010-4 [PMID:24046065]

230. Kiyonaka S, Wakamori M, Miki T, Uriu Y, Nonaka M, Bito H, Beedle AM, Mori E, Hara Y and De Waard M et al.. (2007) RIM1 confers sustained activity and neurotransmitter vesicle anchoring to presynaptic $\mathrm{Ca} 2+$ channels. Nat Neurosci 10: 691-701 [PMID:17496890]

231. Klassen T, Davis C, Goldman A, Burgess D, Chen T, Wheeler D, McPherson J, Bourquin T, Lewis L and Villasana D et al.. (2011) Exome sequencing of ion channel genes reveals complex profiles confounding personal risk assessment in epilepsy. Cell 145: 1036-48 [PMID:21703448]

232. Klugbauer N, Marais E and Hofmann F. (2003) Calcium channel alpha2delta subunits: differential 
expression, function, and drug binding. J. Bioenerg. Biomembr. 35: 639-47 [PMID:15000524]

233. Klugbauer N, Marais E, Lacinová L and Hofmann F. (1999) A T-type calcium channel from mouse brain. Pflugers Arch. 437: 710-5 [PMID:10087148]

234. Komuro H and Rakic P. (1992) Selective role of $\mathrm{N}$-type calcium channels in neuronal migration.Science 257: 806-9 [PMID:1323145]

235. Kordasiewicz HB, Thompson RM, Clark HB and Gomez CM. (2006) C-termini of P/Q-type Ca2+ channel alpha1A subunits translocate to nuclei and promote polyglutamine-mediated toxicity. Hum. Mol. Genet. 15: 1587-99 [PMID:16595610]

236. Kors EE, Haan J, Giffin NJ, Pazdera L, Schnittger C, Lennox GG, Terwindt GM, Vermeulen FL, Van den Maagdenberg AM and Frants RR et al.. (2003) Expanding the phenotypic spectrum of the CACNA1A gene T666M mutation: a description of 5 families with familial hemiplegic migraine. Arch. Neurol. 60: 684-8 [PMID:12756131]

237. Kors EE, Melberg A, Vanmolkot KR, Kumlien E, Haan J, Raininko R, Flink R, Ginjaar HB, Frants RR and Ferrari MD et al.. (2004) Childhood epilepsy, familial hemiplegic migraine, cerebellar ataxia, and a new CACNA1A mutation. Neurology 63: 1136-7 [PMID:15452324]

238. Kors EE, Terwindt GM, Vermeulen FL, Fitzsimons RB, Jardine PE, Heywood P, Love S, van den Maagdenberg AM, Haan J and Frants RR et al.. (2001) Delayed cerebral edema and fatal coma after minor head trauma: role of the CACNA1A calcium channel subunit gene and relationship with familial hemiplegic migraine. Ann. Neurol. 49: 753-60 [PMID:11409427]

239. Koschak A, Reimer D, Huber I, Grabner M, Glossmann H, Engel J and Striessnig J. (2001) alpha 1D (Cav1.3) subunits can form I-type Ca2+ channels activating at negative voltages. J. Biol. Chem. 276: 22100-6 [PMID:11285265]

240. Koschak A, Reimer D, Walter D, Hoda JC, Heinzle T, Grabner M and Striessnig J. (2003) Cav1.4alpha1 subunits can form slowly inactivating dihydropyridine-sensitive L-type $\mathrm{Ca} 2+$ channels lacking Ca2+dependent inactivation. J. Neurosci. 23: 6041-9 [PMID:12853422]

241. Kotturi MF and Jefferies WA. (2005) Molecular characterization of L-type calcium channel splice variants expressed in human T lymphocytes. Mol. Immunol. 42: 1461-74 [PMID:15899519]

242. Kozlov AS, McKenna F, Lee JH, Cribbs LL, Perez-Reyes E, Feltz A and Lambert RC. (1999) Distinct kinetics of cloned T-type $\mathrm{Ca} 2+$ channels lead to differential $\mathrm{Ca} 2+$ entry and frequency-dependence during mock action potentials. Eur. J. Neurosci. 11: 4149-58 [PMID:10594640]

243. Kraus RL, Sinnegger MJ, Glossmann H, Hering S and Striessnig J. (1998) Familial hemiplegic migraine mutations change alpha1A Ca2+ channel kinetics. J. Biol. Chem. 273: 5586-90 [PMID:9488686]

244. Kraus RL, Sinnegger MJ, Koschak A, Glossmann H, Stenirri S, Carrera P and Striessnig J. (2000) Three new familial hemiplegic migraine mutants affect $\mathrm{P} / \mathrm{Q}$-type $\mathrm{Ca}(2+)$ channel kinetics. J. Biol. Chem. 275: 9239-43 [PMID:10734061]

245. Kubota M, Murakoshi T, Saegusa H, Kazuno A, Zong S, Hu Q, Noda T and Tanabe T. (2001) Intact LTP and fear memory but impaired spatial memory in mice lacking $\mathrm{Ca}(\mathrm{v}) 2.3$ (alpha(IE)) channel. Biochem. Biophys. Res. Commun. 282: 242-8 [PMID:11263998]

246. Lalevée N, Rebsamen MC, Barrère-Lemaire S, Perrier E, Nargeot J, Bénitah JP and Rossier MF. (2005) Aldosterone increases T-type calcium channel expression and in vitro beating frequency in neonatal rat cardiomyocytes. Cardiovasc. Res. 67: 216-24 [PMID:15919070]

247. Lamb GD and Walsh T. (1987) Calcium currents, charge movement and dihydropyridine binding in fastand slow-twitch muscles of rat and rabbit. J. Physiol. (Lond.) 393: 595-617 [PMID:2451745]

248. Lampe RA, Defeo PA, Davison MD, Young J, Herman JL, Spreen RC, Horn MB, Mangano TJ and Keith RA. (1993) Isolation and pharmacological characterization of omega-grammotoxin SIA, a novel peptide inhibitor of neuronal voltage-sensitive calcium channel responses. Mol. Pharmacol. 44: 451-60 [PMID:8394998]

249. Langwieser N, Christel CJ, Kleppisch T, Hofmann F, Wotjak CT and Moosmang S. (2010) Homeostatic switch in hebbian plasticity and fear learning after sustained loss of Cav1.2 calcium channels. J. Neurosci. 30: 8367-75 [PMID:20573883]

250. Latour I, Hamid J, Beedle AM, Zamponi GW and Macvicar BA. (2003) Expression of voltage-gated Ca2+ channel subtypes in cultured astrocytes. Glia 41: 347-53 [PMID:12555202]

251. Lee AS, Ra S, Rajadhyaksha AM, Britt JK, De Jesus-Cortes H, Gonzales KL, Lee A, Moosmang S, Hofmann F and Pieper AA et al.. (2012) Forebrain elimination of cacna1c mediates anxiety-like behavior in mice. Mol. Psychiatry 17: 1054-5 [PMID:22665262]

252. Lee JH, Daud AN, Cribbs LL, Lacerda AE, Pereverzev A, Klöckner U, Schneider T and Perez-Reyes E. (1999) Cloning and expression of a novel member of the low voltage-activated T-type calcium channel family. J. Neurosci. 19: 1912-21 [PMID:10066244]

253. Lee JH, Gomora JC, Cribbs LL and Perez-Reyes E. (1999) Nickel block of three cloned T-type calcium channels: low concentrations selectively block alpha1H. Biophys. J. 77: 3034-42 [PMID:10585925]

254. Lee TS, Karl R, Moosmang S, Lenhardt P, Klugbauer N, Hofmann F, Kleppisch T and Welling A. (2006) Calmodulin kinase II is involved in voltage-dependent facilitation of the L-type Cav1.2 calcium channel: Identification of the phosphorylation sites. J. Biol. Chem. 281: 25560-7 [PMID:16820363]

255. Lein ES, Hawrylycz MJ, Ao N, Ayres M, Bensinger A, Bernard A, Boe AF, Boguski MS, Brockway KS and Byrnes EJ et al.. (2007) Genome-wide atlas of gene expression in the adult mouse brain.Nature 445: 16876 [PMID:17151600]

256. Leroy J, Richter W, Mika D, Castro LR, Abi-Gerges A, Xie M, Scheitrum C, Lefebvre F, Schittl J and Mateo $\mathrm{P}$ et al.. (2011) Phosphodiesterase 4B in the cardiac L-type $\mathrm{Ca}^{2+}$ channel complex regulates $\mathrm{Ca}^{2+}$ current 
and protects against ventricular arrhythmias in mice. J. Clin. Invest. 121: 2651-61 [PMID:21670503]

257. Lewis RJ, Nielsen KJ, Craik DJ, Loughnan ML, Adams DA, Sharpe IA, Luchian T, Adams DJ, Bond T and Thomas $L$ et al.. (2000) Novel omega-conotoxins from Conus catus discriminate among neuronal calcium channel subtypes. J. Biol. Chem. 275: 35335-44 [PMID:10938268]

258. Leão RM, Cruz JS, Diniz CR, Cordeiro MN and Beirão PS. (2000) Inhibition of neuronal high-voltage activated calcium channels by the omega-phoneutria nigriventer Tx3-3 peptide toxin. Neuropharmacology 39: 1756-67 [PMID:10884557]

259. Li FF, Li QQ, Tan ZX, Zhang SY, Liu J, Zhao EY, Yu GC, Zhou J, Zhang LM and Liu SL. (2012) A novel mutation in CACNA1S gene associated with hypokalemic periodic paralysis which has a gender difference in the penetrance. J. Mol. Neurosci. 46: 378-83 [PMID:21845430]

260. Li GR, Yang B, Feng J, Bosch RF, Carrier M and Nattel S. (1999) Transmembrane ICa contributes to ratedependent changes of action potentials in human ventricular myocytes. Am. J. Physiol. 276: H98-H106 [PMID:9887022]

261. Li L, Bischofberger J and Jonas P. (2007) Differential gating and recruitment of P/Q-, N-, and R-type Ca2+ channels in hippocampal mossy fiber boutons. J. Neurosci. 27: 13420-9 [PMID:18057200]

262. Liao P, Yu D, Li G, Yong TF, Soon JL, Chua YL and Soong TW. (2007) A smooth muscle Cav1.2 calcium channel splice variant underlies hyperpolarized window current and enhanced state-dependent inhibition by nifedipine. J. Biol. Chem. 282: 35133-42 [PMID:17916557]

263. Lieb A, Scharinger A, Sartori S, Sinnegger-Brauns MJ and Striessnig J. (2012) Structural determinants of CaV1.3 L-type calcium channel gating. Channels (Austin) 6: 197-205 [PMID:22760075]

264. Lin Z, Lin Y, Schorge S, Pan JQ, Beierlein M and Lipscombe D. (1999) Alternative splicing of a short cassette exon in alpha1B generates functionally distinct $\mathrm{N}$-type calcium channels in central and peripheral neurons. J. Neurosci. 19: 5322-31 [PMID:10377343]

265. Liu G, Papa A, Katchman AN, Zakharov SI, Roybal D, Hennessey JA, Kushner J, Yang L, Chen BX and Kushnir A et al.. (2020) Mechanism of adrenergic Ca 1.2 stimulation revealed by proximity proteomics. Nature 577: 695-700 [PMID:31969708]

266. Liu H, De Waard M, Scott VE, Gurnett CA, Lennon VA and Campbell KP. (1996) Identification of three subunits of the high affinity omega-conotoxin MVIIC-sensitive Ca2+ channel. J. Biol. Chem. 271: 13804-10 [PMID:8662888]

267. Liu L, Gonzalez PK, Barrett CF and Rittenhouse AR. (2003) The calcium channel ligand FPL 64176 enhances L-type but inhibits N-type neuronal calcium currents. Neuropharmacology 45: 281-92 [PMID:12842134]

268. Liu X, Yang PS, Yang W and Yue DT. (2010) Enzyme-inhibitor-like tuning of $\mathrm{Ca}(2+)$ channel connectivity with calmodulin. Nature 463: 968-72 [PMID:20139964]

269. Llinás R, Sugimori M, Hillman DE and Cherksey B. (1992) Distribution and functional significance of the Ptype, voltage-dependent Ca2+ channels in the mammalian central nervous system. Trends Neurosci 15: 351-5 [PMID:1382335]

270. Lu ZJ, Pereverzev A, Liu HL, Weiergräber M, Henry M, Krieger A, Smyth N, Hescheler J and Schneider T. (2004) Arrhythmia in isolated prenatal hearts after ablation of the Cav2.3 (alpha1E) subunit of voltagegated Ca2+ channels. Cell. Physiol. Biochem. 14: 11-22 [PMID:14976402]

271. Ludwig A, Flockerzi $V$ and Hofmann F. (1997) Regional expression and cellular localization of the alpha1 and beta subunit of high voltage-activated calcium channels in rat brain. J. Neurosci. 17: 1339-49 [PMID:9006977]

272. Luebke JI, Dunlap K and Turner TJ. (1993) Multiple calcium channel types control glutamatergic synaptic transmission in the hippocampus. Neuron 11: 895-902 [PMID:7902110]

273. Maciel IS, Azevedo VM, Pereira TC, Bogo MR, Souza AH, Gomez MV and Campos MM. (2014) The spinal inhibition of N-type voltage-gated calcium channels selectively prevents scratching behavior in mice. Neuroscience 277: 794-805 [PMID:25108164]

274. Magyar J, lost N, Körtvély A, Bányász T, Virág L, Szigligeti P, Varró A, Opincariu M, Szécsi J and Papp JG et al.. (2000) Effects of endothelin-1 on calcium and potassium currents in undiseased human ventricular myocytes. Pflugers Arch. 441: 144-9 [PMID:11205054]

275. Malmberg AB and Yaksh TL. (1994) Voltage-sensitive calcium channels in spinal nociceptive processing: blockade of $\mathrm{N}$ - and P-type channels inhibits formalin-induced nociception. J. Neurosci. 14: $4882-90$ [PMID:8046458]

276. Mangoni ME, Couette B, Bourinet E, Platzer J, Reimer D, Striessnig J and Nargeot J. (2003) Functional role of L-type Cav1.3 Ca2+ channels in cardiac pacemaker activity. Proc. Natl. Acad. Sci. U.S.A.100: 5543-8 [PMID:12700358]

277. Mangoni ME, Traboulsie A, Leoni AL, Couette B, Marger L, Le Quang K, Kupfer E, Cohen-Solal A, Vilar J and Shin HS et al.. (2006) Bradycardia and slowing of the atrioventricular conduction in mice lacking CaV3.1/alpha1G T-type calcium channels. Circ. Res. 98: 1422-30 [PMID:16690884]

278. Mansergh F, Orton NC, Vessey JP, Lalonde MR, Stell WK, Tremblay F, Barnes S, Rancourt DE and BechHansen NT. (2005) Mutation of the calcium channel gene Cacna1f disrupts calcium signaling, synaptic transmission and cellular organization in mouse retina. Hum. Mol. Genet. 14: 3035-46 [PMID:16155113]

279. Mantuano E, Romano S, Veneziano L, Gellera C, Castellotti B, Caimi S, Testa D, Estienne M, Zorzi G and Bugiani $M$ et al.. (2010) Identification of novel and recurrent CACNA1A gene mutations in fifteen patients with episodic ataxia type 2. J. Neurol. Sci. 291: 30-6 [PMID:20129625]

280. Mantuano E, Veneziano L, Spadaro M, Giunti P, Guida S, Leggio MG, Verriello L, Wood N, Jodice C and 
Frontali M. (2004) Clusters of non-truncating mutations of P/Q type Ca2+ channel subunit $\mathrm{Ca}(\mathrm{v}) 2.1$ causing episodic ataxia 2. J. Med. Genet. 41: e82 [PMID:15173248]

281. Marcantoni A, Calorio C, Hidisoglu E, Chiantia G and Carbone E. (2020) Cav1.2 channelopathies causing autism: new hallmarks on Timothy syndrome. Pflugers Arch 472: 775-789 [PMID:32621084]

282. Marcantoni A, Vandael DH, Mahapatra S, Carabelli V, Sinnegger-Brauns MJ, Striessnig J and Carbone E. (2010) Loss of Cav1.3 channels reveals the critical role of L-type and BK channel coupling in pacemaking mouse adrenal chromaffin cells. J. Neurosci. 30: 491-504 [PMID:20071512]

283. Marshall MR, Clark 3rd JP, Westenbroek R, Yu FH, Scheuer T and Catterall WA. (2011) Functional roles of a C-terminal signaling complex of CaV1 channels and A-kinase anchoring protein 15 in brain neurons. J. Biol. Chem. 286: 12627-39 [PMID:21224388]

284. Martin RL, Lee JH, Cribbs LL, Perez-Reyes E and Hanck DA. (2000) Mibefradil block of cloned T-type calcium channels. J. Pharmacol. Exp. Ther. 295: 302-8 [PMID:10991994]

285. Mathur VS. (2000) A new pharmacological class of drug for the management of pain.Seminars in Anesthesia, Perioperative Medicine and Pain 19: 67-75

286. Matsuda Y, Saegusa H, Zong S, Noda T and Tanabe T. (2001) Mice lacking Ca(v)2.3 (alpha1E) calcium channel exhibit hyperglycemia. Biochem. Biophys. Res. Commun. 289: 791-5 [PMID:11735114]

287. Matsuyama Z, Wakamori M, Mori Y, Kawakami H, Nakamura S and Imoto K. (1999) Direct alteration of the $\mathrm{P} / \mathrm{Q}$-type Ca2+ channel property by polyglutamine expansion in spinocerebellar ataxia 6. J. Neurosci. 19: RC14 [PMID:10366652]

288. Matthews E, Labrum R, Sweeney MG, Sud R, Haworth A, Chinnery PF, Meola G, Schorge S, Kullmann DM and Davis MB et al.. (2009) Voltage sensor charge loss accounts for most cases of hypokalemic periodic paralysis. Neurology 72: 1544-7 [PMID:19118277]

289. Matthews EA, Bee LA, Stephens GJ and Dickenson AH. (2007) The Cav2.3 calcium channel antagonist SNX-482 reduces dorsal horn neuronal responses in a rat model of chronic neuropathic pain. Eur. J. Neurosci. 25: 3561-9 [PMID:17610575]

290. Matza D, Badou A, Kobayashi KS, Goldsmith-Pestana K, Masuda Y, Komuro A, McMahon-Pratt D, Marchesi VT and Flavell RA. (2008) A scaffold protein, AHNAK1, is required for calcium signaling during $T$ cell activation. Immunity 28: 64-74 [PMID:18191595]

291. McDonough SI, Boland LM, Mintz IM and Bean BP. (2002) Interactions among toxins that inhibit N-type and P-type calcium channels. J. Gen. Physiol. 119: 313-28 [PMID:11929883]

292. McDonough SI, Lampe RA, Keith RA and Bean BP. (1997) Voltage-dependent inhibition of N-and P-type calcium channels by the peptide toxin omega-grammotoxin-SIA. Mol. Pharmacol. 52: 1095-104 [PMID:9415720]

293. McDonough SI, Swartz KJ, Mintz IM, Boland LM and Bean BP. (1996) Inhibition of calcium channels in rat central and peripheral neurons by omega-conotoxin MVIIC. J. Neurosci. 16: 2612-23 [PMID:8786437]

294. McGivern JG. (2006) Pharmacology and drug discovery for T-type calcium channels.CNS Neurol Disord Drug Targets 5: 587-603 [PMID:17168744]

295. McGuire D, Bowersox S, Fellmann JD and Luther RR. (1997) Sympatholysis after neuron-specific, N-type, voltage-sensitive calcium channel blockade: first demonstration of $\mathrm{N}$-channel function in humans. $J$. Cardiovasc. Pharmacol. 30: 400-3 [PMID:9300326]

296. McKay BE, McRory JE, Molineux ML, Hamid J, Snutch TP, Zamponi GW and Turner RW. (2006) Ca(V)3 T-type calcium channel isoforms differentially distribute to somatic and dendritic compartments in rat central neurons. Eur. J. Neurosci. 24: 2581-94 [PMID:17100846]

297. McKinney BC and Murphy GG. (2006) The L-Type voltage-gated calcium channel Cav1.3 mediates consolidation, but not extinction, of contextually conditioned fear in mice. Learn. Mem. 13: 584-9 [PMID:17015855]

298. McKinney BC, Sze W, Lee B and Murphy GG. (2009) Impaired long-term potentiation and enhanced neuronal excitability in the amygdala of $\mathrm{Ca}(\mathrm{V}) 1.3$ knockout mice. Neurobiol Learn Mem 92: 519-28 [PMID:19595780]

299. McNaughton NC and Randall AD. (1997) Electrophysiological properties of the human N-type Ca2+ channel: I. Channel gating in Ca2+, Ba2+ and Sr2+ containing solutions. Neuropharmacology 36: 895-915 [PMID:9257935]

300. McRory JE, Hamid J, Doering CJ, Garcia E, Parker R, Hamming K, Chen L, Hildebrand M, Beedle AM and Feldcamp L et al.. (2004) The CACNA1F gene encodes an L-type calcium channel with unique biophysical properties and tissue distribution. J. Neurosci. 24: 1707-18 [PMID:14973233]

301. McRory JE, Santi CM, Hamming KS, Mezeyova J, Sutton KG, Baillie DL, Stea A and Snutch TP. (2001) Molecular and functional characterization of a family of rat brain T-type calcium channels. J. Biol. Chem. 276: 3999-4011 [PMID:11073957]

302. Melliti K, Grabner M and Seabrook GR. (2003) The familial hemiplegic migraine mutation R192Q reduces G-protein-mediated inhibition of $P / Q$-type $(\mathrm{Ca}(\mathrm{V}) 2.1)$ calcium channels expressed in human embryonic kidney cells. J. Physiol. (Lond.) 546: 337-47 [PMID:12527722]

303. Mermelstein PG, Foehring RC, Tkatch T, Song WJ, Baranauskas G and Surmeier DJ. (1999) Properties of Q-type calcium channels in neostriatal and cortical neurons are correlated with beta subunit expression. $J$. Neurosci. 19: 7268-77 [PMID:10460233]

304. Mewes T and Ravens U. (1994) L-type calcium currents of human myocytes from ventricle of non-failing and failing hearts and from atrium. J. Mol. Cell. Cardiol.26: 1307-20 [PMID:7869391]

305. Michna M, Knirsch M, Hoda JC, Muenkner S, Langer P, Platzer J, Striessnig J and Engel J. (2003) Cav1.3 (alpha1D) Ca2+ currents in neonatal outer hair cells of mice. J. Physiol. (Lond.) 553: 747-58 
[PMID:14514878]

306. Mintz IM. (1994) Block of Ca channels in rat central neurons by the spider toxin omega-Aga-IIIAJ. Neurosci. 14: 2844-53 [PMID:8182443]

307. Mintz IM, Adams ME and Bean BP. (1992) P-type calcium channels in rat central and peripheral neurons. Neuron 9: 85-95 [PMID:1321648]

308. Mintz IM, Sabatini BL and Regehr WG. (1995) Calcium control of transmitter release at a cerebellar synapse. Neuron 15: 675-88 [PMID:7546746]

309. Mintz IM, Venema VJ, Swiderek KM, Lee TD, Bean BP and Adams ME. (1992) P-type calcium channels blocked by the spider toxin omega-Aga-IVA. Nature 355: $827-9$ [PMID:1311418]

310. Mitchell JW, Larsen JK and Best PM. (2002) Identification of the calcium channel alpha 1E (Ca(v)2.3) isoform expressed in atrial myocytes. Biochim. Biophys. Acta 1577: 17-26 [PMID:12151091]

311. Mochida S, Few AP, Scheuer T and Catterall WA. (2008) Regulation of presynaptic $\mathrm{Ca}(\mathrm{V}) 2.1$ channels by $\mathrm{Ca} 2+$ sensor proteins mediates short-term synaptic plasticity. Neuron 57: 210-6 [PMID:18215619]

312. Monnier N, Procaccio V, Stieglitz P and Lunardi J. (1997) Malignant-hyperthermia susceptibility is associated with a mutation of the alpha 1-subunit of the human dihydropyridine-sensitive L-type voltagedependent calcium-channel receptor in skeletal muscle. Am. J. Hum. Genet.60: 1316-25 [PMID:9199552]

313. Monteil A, Chemin J, Bourinet E, Mennessier G, Lory P and Nargeot J. (2000) Molecular and functional properties of the human alpha(1G) subunit that forms T-type calcium channels. J. Biol. Chem. 275: 6090100 [PMID:10692398]

314. Monteil A, Chemin J, Leuranguer V, Altier C, Mennessier G, Bourinet E, Lory P and Nargeot J. (2000) Specific properties of T-type calcium channels generated by the human alpha 1 I subunit. J. Biol. Chem. 275: 16530-5 [PMID:10749850]

315. Moosmang S, Haider N, Klugbauer N, Adelsberger H, Langwieser N, Müller J, Stiess M, Marais E, Schulla $\checkmark$ and Lacinova $L$ et al.. (2005) Role of hippocampal Cav1.2 Ca2+ channels in NMDA receptorindependent synaptic plasticity and spatial memory. J. Neurosci. 25: 9883-92 [PMID:16251435]

316. Moosmang S, Schulla V, Welling A, Feil R, Feil S, Wegener JW, Hofmann F and Klugbauer N. (2003) Dominant role of smooth muscle L-type calcium channel Cav1.2 for blood pressure regulation. EMBO J. 22: 6027-34 [PMID:14609949]

317. Morgans CW, Gaughwin P and Maleszka R. (2001) Expression of the alpha1F calcium channel subunit by photoreceptors in the rat retina. Mol. Vis. 7: 202-9 [PMID:11526344]

318. Muller YL, Hanson RL, Zimmerman C, Harper I, Sutherland J, Kobes S, International Type 2 Diabetes 1q Consortium, Knowler WC, Bogardus C and Baier LJ. (2007) Variants in the Ca V 2.3 (alpha 1E) subunit of voltage-activated $\mathrm{Ca} 2+$ channels are associated with insulin resistance and type 2 diabetes in Pima Indians. Diabetes 56: 3089-94 [PMID:17720895]

319. Murakami M, Nakagawasai O, Fujii S, Kameyama K, Murakami S, Hozumi S, Esashi A, Taniguchi R, Yanagisawa T and Tan-no K et al.. (2001) Antinociceptive action of amlodipine blocking N-type Ca2+ channels at the primary afferent neurons in mice. Eur. J. Pharmacol. 419: 175-81 [PMID:11426839]

320. Murakami M, Nakagawasai O, Yanai K, Nunoki K, Tan-No K, Tadano T and lijima T. (2007) Modified behavioral characteristics following ablation of the voltage-dependent calcium channel beta3 subunit. Brain Res. 1160: 102-12 [PMID:17588550]

321. Murakami M, Ohba T, Wu TW, Fujisawa S, Suzuki T, Takahashi Y, Takahashi E, Watanabe H, Miyoshi I and Ono K et al.. (2007) Modified sympathetic regulation in N-type calcium channel null-mouse Biochem. Biophys. Res. Commun. 354: 1016-20 [PMID:17275790]

322. Murbartián J, Arias JM and Perez-Reyes E. (2004) Functional impact of alternative splicing of human Ttype Cav3.3 calcium channels. J. Neurophysiol. 92: 3399-407 [PMID:15254077]

323. Myoga MH and Regehr WG. (2011) Calcium microdomains near R-type calcium channels control the induction of presynaptic long-term potentiation at parallel fiber to purkinje cell synapses. J. Neurosci. 31: 5235-43 [PMID:21471358]

324. Müller R, Struck H, Ho MS, Brockhaus-Dumke A, Klosterkötter J, Broich K, Hescheler J, Schneider T and Weiergräber M. (2012) Atropine-sensitive hippocampal $\theta$ oscillations are mediated by Cav2.3 R-type $\mathrm{Ca}^{2+}$ channels. Neuroscience 205: 125-39 [PMID:22240250]

325. Müllner C, Broos LA, van den Maagdenberg AM and Striessnig J. (2004) Familial hemiplegic migraine type 1 mutations K1336E, W1684R, and V1696I alter Cav2.1 Ca2+ channel gating: evidence for beta-subunit isoform-specific effects. J. Biol. Chem. 279: 51844-50 [PMID:15448138]

326. N'gouemo P, Faingold CL and Morad M. (2009) Calcium channel dysfunction in inferior colliculus neurons of the genetically epilepsy-prone rat. Neuropharmacology 56: 665-75 [PMID:19084544]

327. Nakamura M, Ito S, Piao CH, Terasaki H and Miyake Y. (2003) Retinal and optic disc atrophy associated with a CACNA1F mutation in a Japanese family. Arch. Ophthalmol. 121: 1028-33 [PMID:12860808]

328. Nakamura M, Ito S, Terasaki $\mathrm{H}$ and Miyake $\mathrm{Y}$. (2001) Novel CACNA1F mutations in Japanese patients with incomplete congenital stationary night blindness. Invest. Ophthalmol. Vis. Sci. 42: 1610-6 [PMID:11381068]

329. Nanou E and Catterall WA. (2018) Calcium Channels, Synaptic Plasticity, and Neuropsychiatric Disease. Neuron 98: 466-481 [PMID:29723500]

330. Naylor MJ, Rancourt DE and Bech-Hansen NT. (2000) Isolation and characterization of a calcium channel gene, Cacna1f, the murine orthologue of the gene for incomplete X-linked congenital stationary night blindness. Genomics 66: 324-7 [PMID:10873387]

331. Nelson MT, Joksovic PM, Perez-Reyes E and Todorovic SM. (2005) The endogenous redox agent L- 
cysteine induces T-type Ca2+ channel-dependent sensitization of a novel subpopulation of rat peripheral nociceptors. J. Neurosci. 25: 8766-75 [PMID:16177046]

332. Newcomb R, Szoke B, Palma A, Wang G, Chen Xh, Hopkins W, Cong R, Miller J, Urge L and TarczyHornoch K et al.. (1998) Selective peptide antagonist of the class E calcium channel from the venom of the tarantula Hysterocrates gigas. Biochemistry 37: 15353-62 [PMID:9799496]

333. Newton PM, Orr CJ, Wallace MJ, Kim C, Shin HS and Messing RO. (2004) Deletion of N-type calcium channels alters ethanol reward and reduces ethanol consumption in mice. J. Neurosci. 24: 9862-9 [PMID:15525770]

334. Nimmrich V and Gross G. (2012) P/Q-type calcium channel modulators. Br. J. Pharmacol. 167: 741-59 [PMID:22670568]

335. Nokin P, Clinet M, Beaufort P, Meysmans L, Laruel R and Chatelain P. (1990) SR 33557, a novel calcium entry blocker. II. Interactions with 1,4-dihydropyridine, phenylalkylamine and benzothiazepine binding sites in rat heart sarcolemmal membranes. J. Pharmacol. Exp. Ther. 255: 600-7 [PMID:2147036]

336. Nowycky MC, Fox AP and Tsien RW. (1985) Three types of neuronal calcium channel with different calcium agonist sensitivity. Nature 316: 440-3 [PMID:2410796]

337. O'Roak BJ, Vives L, Girirajan S, Karakoc E, Krumm N, Coe BP, Levy R, Ko A, Lee C and Smith JDet al.. (2012) Sporadic autism exomes reveal a highly interconnected protein network of de novo mutations. Nature 485: 246-50 [PMID:22495309]

338. Obermair GJ, Kugler G, Baumgartner S, Tuluc P, Grabner M and Flucher BE. (2005) The Ca2+ channel alpha2delta-1 subunit determines $\mathrm{Ca} 2+$ current kinetics in skeletal muscle but not targeting of alpha1S or excitation-contraction coupling. J. Biol. Chem. 280: 2229-37 [PMID:15536090]

339. Ogawa T, Kashiwagi A, Kikkawa R and Shigeta Y. (1995) Increase of voltage-sensitive calcium channels and calcium accumulation in skeletal muscles of streptozocin-induced diabetic rats. Metab. Clin. Exp. 44: 1455-61 [PMID:7476334]

340. Okayama S, Imagawa K, Naya N, Iwama H, Somekawa S, Kawata H, Horii M, Nakajima T, Uemura S and Saito Y. (2006) Blocking T-type Ca2+ channels with efonidipine decreased plasma aldosterone concentration in healthy volunteers. Hypertens. Res. 29: 493-7 [PMID:17044661]

341. Olivera BM, Miljanich GP, Ramachandran J and Adams ME. (1994) Calcium channel diversity and neurotransmitter release: the omega-conotoxins and omega-agatoxins. Annu Rev Biochem 63: 823-67 [PMID:7979255]

342. Oliveria SF, Dittmer PJ, Youn DH, Dell'Acqua ML and Sather WA. (2012) Localized calcineurin confers Ca2+-dependent inactivation on neuronal L-type Ca2+ channels. J. Neurosci. 32: 15328-37 [PMID:23115171]

343. Olson PA, Tkatch T, Hernandez-Lopez S, Ulrich S, Ilijic E, Mugnaini E, Zhang H, Bezprozvanny I and Surmeier DJ. (2005) G-protein-coupled receptor modulation of striatal CaV1.3 L-type Ca2+ channels is dependent on a Shank-binding domain. J. Neurosci. 25: 1050-62 [PMID:15689540]

344. Omilusik K, Priatel JJ, Chen X, Wang YT, Xu H, Choi KB, Gopaul R, Mclntyre-Smith A, Teh HS and Tan R et al.. (2011) The $\mathrm{Ca}(\mathrm{v}) 1.4$ calcium channel is a critical regulator of $\mathrm{T}$ cell receptor signaling and naive $\mathrm{T}$ cell homeostasis. Immunity 35: 349-60 [PMID:21835646]

345. Ophoff RA, Terwindt GM, Vergouwe MN, van Eijk R, Oefner PJ, Hoffman SM, Lamerdin JE, Mohrenweiser HW, Bulman DE and Ferrari M et al.. (1996) Familial hemiplegic migraine and episodic ataxia type-2 are caused by mutations in the Ca2+ channel gene CACNL1A4. Cell 87: 543-52 [PMID:8898206]

346. Ortner NJ, Bock G, Dougalis A, Kharitonova M, Duda J, Hess S, Tuluc P, Pomberger T, Stefanova N and Pitterl F et al.. (2017) Lower Affinity of Isradipine for L-Type Ca ${ }^{2+}$ Channels during Substantia Nigra Dopamine Neuron-Like Activity: Implications for Neuroprotection in Parkinson's Disease. J. Neurosci. 37: 6761-6777 [PMID:28592699]

347. Ortner NJ, Kaserer T, Copeland JN and Striessnig J. (2020) De novo CACNA1D C2+ channelopathies: clinical phenotypes and molecular mechanism. Pflugers Arch 472: 755-773 [PMID:32583268]

348. Ortner NJ, Pinggera A, Hofer NT, Siller A, Brandt N, Raffeiner A, Vilusic K, Lang I, Blum K and Obermair GJ et al.. (2020) RBP2 stabilizes slow Cav1.3 $\mathrm{Ca}^{2+}$ channel inactivation properties of cochlear inner hair cells. Pflugers Arch 472: 3-25 [PMID:31848688]

349. Osanai M, Saegusa H, Kazuno AA, Nagayama S, Hu Q, Zong S, Murakoshi T and Tanabe T. (2006) Altered cerebellar function in mice lacking CaV2.3 Ca2+ channel. Biochem. Biophys. Res. Commun. 344: 920-5 [PMID:16631598]

350. Pan JQ and Lipscombe D. (2000) Alternative splicing in the cytoplasmic II-III loop of the N-type Ca channel alpha 1B subunit: functional differences are beta subunit-specific. J. Neurosci. 20: 4769-75 [PMID:10864934]

351. Pang C, Crump SM, Jin L, Correll RN, Finlin BS, Satin J and Andres DA. (2010) Rem GTPase interacts with the proximal CaV1.2 C-terminus and modulates calcium-dependent channel inactivation. Channels (Austin) 4: 192-202 [PMID:20458179]

352. Papanayotou C, De Almeida I, Liao P, Oliveira NM, Lu SQ, Kougioumtzidou E, Zhu L, Shaw A, Sheng G and Streit A et al.. (2013) Calfacilitin is a calcium channel modulator essential for initiation of neural plate development. Nat Commun 4: 1837 [PMID:23673622]

353. Parent L, Schneider T, Moore CP and Talwar D. (1997) Subunit regulation of the human brain alpha 1E calcium channel. J. Membr. Biol. 160: 127-40 [PMID:9354705]

354. Park CY, Shcheglovitov A and Dolmetsch R. (2010) The CRAC channel activator STIM1 binds and inhibits L-type voltage-gated calcium channels. Science 330: 101-5 [PMID:20929812] 
355. Park JH, Choi JK, Lee E, Lee JK, Rhim H, Seo SH, Kim Y, Doddareddy MR, Pae AN, Kang J and Roh EJ. (2007) Lead discovery and optimization of T-type calcium channel blockers. Bioorg. Med. Chem. 15: 140919 [PMID:17150365]

356. Patten M, Maas R, Bauer P, Lüderitz B, Sonntag F, Dluzniewski M, Hatala R, Opolski G, Müller HW and Meinertz T et al.. (2004) Suppression of paroxysmal atrial tachyarrhythmias--results of the SOPAT trial. Eur. Heart J. 25: 1395-404 [PMID:15321697]

357. Pelzmann B, Schaffer P, Bernhart E, Lang P, Mächler H, Rigler B and Koidl B. (1998) L-type calcium current in human ventricular myocytes at a physiological temperature from children with tetralogy of Fallot. Cardiovasc. Res. 38: 424-32 [PMID:9709403]

358. Peng S, Hajela RK and Atchison WD. (2002) Characteristics of block by Pb2+ of function of human neuronal L-, N-, and R-type Ca2+ channels transiently expressed in human embryonic kidney 293 cells. Mol. Pharmacol. 62: 1418-30 [PMID:12435810]

359. Penn RD and Paice JA. (2000) Adverse effects associated with the intrathecal administration of ziconotide. Pain 85: 291-6 [PMID:10692631]

360. Pereverzev A, Klöckner U, Henry M, Grabsch H, Vajna R, Olyschläger S, Viatchenko-Karpinski S, Schröder R, Hescheler J and Schneider T. (1998) Structural diversity of the voltage-dependent Ca2+ channel alpha1E-subunit. Eur. J. Neurosci. 10: 916-25 [PMID:9753159]

361. Pereverzev A, Mikhna M, Vajna R, Gissel C, Henry M, Weiergräber M, Hescheler J, Smyth N and Schneider T. (2002) Disturbances in glucose-tolerance, insulin-release, and stress-induced hyperglycemia upon disruption of the $\mathrm{Ca}(\mathrm{v}) 2.3$ (alpha 1E) subunit of voltage-gated $\mathrm{Ca}(2+)$ channels. Mol. Endocrinol. 16: 884-95 [PMID:11923483]

362. Perez-Reyes E. (2003) Molecular physiology of low-voltage-activated t-type calcium channels.Physiol. Rev. 83: 117-61 [PMID:12506128]

363. Perez-Reyes E, Cribbs LL, Daud A, Lacerda AE, Barclay J, Williamson MP, Fox M, Rees M and Lee JH. (1998) Molecular characterization of a neuronal low-voltage-activated T-type calcium channel. Nature 391: 896-900 [PMID:9495342]

364. Peterson BZ, DeMaria CD, Adelman JP and Yue DT. (1999) Calmodulin is the Ca2+ sensor for Ca2+ dependent inactivation of L-type calcium channels. Neuron 22: 549-58 [PMID:10197534]

365. Pietrobon D and Striessnig J. (2003) Neurobiology of migraine.Nat Rev Neurosci 4: 386-98 [PMID:12728266]

366. Pignier C and Potreau D. (2000) Characterization of nifedipine-resistant calcium current in neonatal rat ventricular cardiomyocytes. Am. J. Physiol. Heart Circ. Physiol.279: H2259-68 [PMID:11045961]

367. Pirone A, Schredelseker J, Tuluc P, Gravino E, Fortunato G, Flucher BE, Carsana A, Salvatore F and Grabner M. (2010) Identification and functional characterization of malignant hyperthermia mutation T1354S in the outer pore of the Cavalpha1S-subunit. Am. J. Physiol., Cell Physiol.299: C1345-54 [PMID:20861472]

368. Pitt GS. (2007) Calmodulin and CaMKII as molecular switches for cardiac ion channels.Cardiovasc. Res. 73: 641-7 [PMID:17137569]

369. Pizarro G, Fitts R, Uribe I and Ríos E. (1989) The voltage sensor of excitation-contraction coupling in skeletal muscle. Ion dependence and selectivity. J. Gen. Physiol. 94: 405-28 [PMID:2481710]

370. Platzer J, Engel J, Schrott-Fischer A, Stephan K, Bova S, Chen H, Zheng H and Striessnig J. (2000) Congenital deafness and sinoatrial node dysfunction in mice lacking class D L-type Ca2+ channels. Cell 102: 89-97 [PMID:10929716]

371. Plummer MR, Logothetis DE and Hess P. (1989) Elementary properties and pharmacological sensitivities of calcium channels in mammalian peripheral neurons. Neuron 2: 1453-63 [PMID:2560643]

372. Polster A, Dittmer PJ, Perni S, Bichraoui H, Sather WA and Beam KG. (2018) Stac Proteins Suppress $\mathrm{Ca}^{2+}$-Dependent Inactivation of Neuronal I-type $\mathrm{Ca}^{2+}$ Channels. J Neurosci 38: 9215-9227 [PMID:30201773]

373. Polster A, Perni S, Bichraoui H and Beam KG. (2015) Stac adaptor proteins regulate trafficking and function of muscle and neuronal L-type Ca2+ channels. Proc Natl Acad Sci U S A112: 602-6 [PMID:25548159]

374. Poole-Wilson PA, Lubsen J, Kirwan BA, van Dalen FJ, Wagener G, Danchin N, Just H, Fox KA, Pocock SJ and Clayton TC et al.. (2004) Effect of long-acting nifedipine on mortality and cardiovascular morbidity in patients with stable angina requiring treatment (ACTION trial): randomised controlled trial. Lancet 364: 849-57 [PMID:15351192]

375. Prinz H and Striessnig J. (1993) Ligand-induced accelerated dissociation of (+)-cis-diltiazem from L-type $\mathrm{Ca} 2+$ channels is simply explained by competition for individual attachment points. J. Biol. Chem. 268: 18580-5 [PMID:8395510]

376. Ptácek LJ, Tawil R, Griggs RC, Engel AG, Layzer RB, Kwieciński H, McManis PG, Santiago L, Moore M and Fouad $\mathrm{G}$ et al.. (1994) Dihydropyridine receptor mutations cause hypokalemic periodic paralysis. Cell 77: 863-8 [PMID:8004673]

377. Pérez-Alvarez A, Hernández-Vivanco A, Caba-González JC and Albillos A. (2011) Different roles attributed to Cav1 channel subtypes in spontaneous action potential firing and fine tuning of exocytosis in mouse chromaffin cells. J. Neurochem. 116: 105-21 [PMID:21054386]

378. Pérez-Vizcaíno F, Tamargo J, Hof RP and Rüegg UT. (1993) Vascular selectivity of seven prototype calcium antagonists: a study at the single cell level. J. Cardiovasc. Pharmacol. 22: 768-75 [PMID:7506331]

379. Qin N, Yagel S, Momplaisir ML, Codd EE and D'Andrea MR. (2002) Molecular cloning and 
characterization of the human voltage-gated calcium channel alpha(2)delta-4 subunit. Mol. Pharmacol. 62: 485-96 [PMID:12181424]

380. Qu Y, Baroudi G, Yue Y and Boutjdir M. (2005) Novel molecular mechanism involving alpha1D (Cav1.3) Ltype calcium channel in autoimmune-associated sinus bradycardia. Circulation 111: 3034-41 [PMID:15939813]

381. Qu Y, Baroudi G, Yue Y, El-Sherif N and Boutjdir M. (2005) Localization and modulation of \{alpha\}1D (Cav1.3) L-type Ca channel by protein kinase A. Am. J. Physiol. Heart Circ. Physiol. 288: H2123-30 [PMID:15615842]

382. Ramachandran KV, Hennessey JA, Barnett AS, Yin X, Stadt HA, Foster E, Shah RA, Yazawa M, Dolmetsch RE and Kirby ML et al.. (2013) Calcium influx through L-type CaV1.2 Ca2+ channels regulates mandibular development. J. Clin. Invest. 123: 1638-46 [PMID:23549079]

383. Ramakrishnan NA, Drescher MJ and Drescher DG. (2009) Direct interaction of otoferlin with syntaxin 1A, SNAP-25, and the L-type voltage-gated calcium channel Cav1.3. J. Biol. Chem. 284: 1364-72 [PMID:19004828]

384. Randall A and Tsien RW. (1995) Pharmacological dissection of multiple types of Ca2+ channel currents in rat cerebellar granule neurons. J. Neurosci. 15: 2995-3012 [PMID:7722641]

385. Randall AD and Tsien RW. (1997) Contrasting biophysical and pharmacological properties of T-type and R-type calcium channels. Neuropharmacology 36: 879-93 [PMID:9257934]

386. Regan LJ, Sah DW and Bean BP. (1991) Ca2+ channels in rat central and peripheral neurons: highthreshold current resistant to dihydropyridine blockers and omega-conotoxin. Neuron 6: 269-80 [PMID:1847065]

387. Regehr WG and Mintz IM. (1994) Participation of multiple calcium channel types in transmission at single climbing fiber to Purkinje cell synapses. Neuron 12: 605-13 [PMID:8155322]

388. Restituito S, Thompson RM, Eliet J, Raike RS, Riedl M, Charnet P and Gomez CM. (2000) The polyglutamine expansion in spinocerebellar ataxia type 6 causes a beta subunit-specific enhanced activation of P/Q-type calcium channels in Xenopus oocytes. J. Neurosci. 20: 6394-403 [PMID:10964945]

389. Reuter H. (1979) Properties of two inward membrane currents in the heartAnnu Rev Physiol 41: 413-24 [PMID:373598]

390. Reuter H. (1983) Calcium channel modulation by neurotransmitters, enzymes and drugs.Nature 301: 56974 [PMID:6131381]

391. Richards KS, Swensen AM, Lipscombe D and Bommert K. (2007) Novel CaV2.1 clone replicates many properties of Purkinje cell CaV2.1 current. Eur. J. Neurosci. 26: 2950-61 [PMID:18001290]

392. Ridgeway B, Wallace M and Gerayli A. (2000) Ziconotide for the treatment of severe spasticity after spinal cord injury. Pain 85: 287-9 [PMID:10692630]

393. Rijkers K, Mescheriakova J, Majoie M, Lemmens E, van Wijk X, Philippens M, Van Kranen-Mastenbroek V, Schijns O, Vles J and Hoogland G. (2010) Polymorphisms in CACNA1E and Camk2d are associated with seizure susceptibility of Sprague-Dawley rats. Epilepsy Res. 91: 28-34 [PMID:20638246]

394. Robert V, Triffaux E, Paulet PE, Guéry JC, Pelletier L and Savignac M. (2014) Protein kinase C-dependent activation of CaV1.2 channels selectively controls human TH2-lymphocyte functions. J. Allergy Clin. Immunol. 133: 1175-83 [PMID:24365142]

395. Romaniello R, Zucca C, Tonelli A, Bonato S, Baschirotto C, Zanotta N, Epifanio R, Righini A, Bresolin N and Bassi MT et al.. (2010) A wide spectrum of clinical, neurophysiological and neuroradiological abnormalities in a family with a novel CACNA1A mutation. J. Neurol. Neurosurg. Psychiatr. 81: 840-3 [PMID:20682717]

396. Rosa N, Triffaux E, Robert V, Mars M, Klein M, Bouchaud G, Canivet A, Magnan A, Guéry JC and Pelletier $L$ et al.. (2018) The $\beta$ and $\alpha 2 \delta$ auxiliary subunits of voltage-gated calcium channel 1 (Ca 1 ) are required for $\mathrm{T}_{\mathrm{H}} 2$ lymphocyte function and acute allergic airway inflammation. J. Allergy Clin. Immunol. 142: 892-903.e8 [PMID:29129580]

397. Ruth P, Röhrkasten A, Biel M, Bosse E, Regulla S, Meyer HE, Flockerzi V and Hofmann F. (1989) Primary structure of the beta subunit of the DHP-sensitive calcium channel from skeletal muscle. Science 245: 1115-8 [PMID:2549640]

398. Ríos E, Pizarro G and Stefani E. (1992) Charge movement and the nature of signal transduction in skeletal muscle excitation-contraction coupling. Annu. Rev. Physiol. 54: 109-33 [PMID:1562172]

399. Saegusa H, Kurihara T, Zong S, Kazuno A, Matsuda Y, Nonaka T, Han W, Toriyama H and Tanabe T. (2001) Suppression of inflammatory and neuropathic pain symptoms in mice lacking the N-type Ca2+ channel. EMBO J. 20: 2349-56 [PMID:11350923]

400. Saegusa H, Kurihara T, Zong S, Minowa O, Kazuno A, Han W, Matsuda Y, Yamanaka H, Osanai M and Noda T et al.. (2000) Altered pain responses in mice lacking alpha 1E subunit of the voltage-dependent Ca2+ channel. Proc. Natl. Acad. Sci. U.S.A. 97: 6132-7 [PMID:10801976]

401. Safa P, Boulter J and Hales TG. (2001) Functional properties of Cav1.3 (alpha1D) L-type Ca2+ channel splice variants expressed by rat brain and neuroendocrine GH3 cells. J. Biol. Chem. 276: 38727-37 [PMID:11514547]

402. Santi CM, Cayabyab FS, Sutton KG, McRory JE, Mezeyova J, Hamming KS, Parker D, Stea A and Snutch TP. (2002) Differential inhibition of T-type calcium channels by neuroleptics. J. Neurosci. 22: 396-403 [PMID:11784784]

403. Schierberl K, Giordano T, Satpute S, Hao J, Kaur G, Hofmann F, Moosmang S, Striessnig J and Rajadhyaksha A. (2012) Cav 1.3 L-type Ca (2+) channels mediate long-term adaptation in dopamine D2L- 
mediated GluA1 trafficking in the dorsal striatum following cocaine exposure. Channels (Austin) 6: 11-7 [PMID:22419037]

404. Schneider T, Wei X, Olcese R, Costantin JL, Neely A, Palade P, Perez-Reyes E, Qin N, Zhou J and Crawford GD. (1994) Molecular analysis and functional expression of the human type E neuronal Ca2+ channel alpha 1 subunit. Recept. Channels 2: 255-70 [PMID:7536609]

405. Scholl UI, Goh G, Stölting G, de Oliveira RC, Choi M, Overton JD, Fonseca AL, Korah R, Starker LF and Kunstman JW et al.. (2013) Somatic and germline CACNA1D calcium channel mutations in aldosteroneproducing adenomas and primary aldosteronism. Nat. Genet. 45: 1050-4 [PMID:23913001]

406. Scholl UI, Stölting G, Nelson-Williams C, Vichot AA, Choi M, Loring E, Prasad ML, Goh G, Carling T and Juhlin CC et al.. (2015) Recurrent gain of function mutation in calcium channel CACNA1H causes earlyonset hypertension with primary aldosteronism. Elife 4: e06315 [PMID:25907736]

407. Scholze A, Plant TD, Dolphin AC and Nürnberg B. (2001) Functional expression and characterization of a voltage-gated CaV1.3 (alpha1D) calcium channel subunit from an insulin-secreting cell line. Mol.

Endocrinol. 15: 1211-21 [PMID:11435619]

408. Schrauwen I, Helfmann S, Inagaki A, Predoehl F, Tabatabaiefar MA, Picher MM, Sommen M, Seco CZ, Oostrik $\mathrm{J}$ and Kremer $\mathrm{H}$ et al.. (2012) A mutation in CABP2, expressed in cochlear hair cells, causes autosomal-recessive hearing impairment. Am. J. Hum. Genet.91: 636-45 [PMID:22981119]

409. Schrier AD, Wang H, Talley EM, Perez-Reyes E and Barrett PQ. (2001) alpha1H T-type Ca2+ channel is the predominant subtype expressed in bovine and rat zona glomerulosa. Am. J. Physiol., Cell Physiol.280: C265-72 [PMID:11208520]

410. Schulla V, Renström E, Feil R, Feil S, Franklin I, Gjinovci A, Jing XJ, Laux D, Lundquist I and Magnuson MA et al.. (2003) Impaired insulin secretion and glucose tolerance in beta cell-selective Ca(v)1.2 Ca2+ channel null mice. EMBO J. 22: 3844-54 [PMID:12881419]

411. Schultz D, Mikala G, Yatani A, Engle DB, lles DE, Segers B, Sinke RJ, Weghuis DO, Klöckner U and Wakamori M et al.. (1993) Cloning, chromosomal localization, and functional expression of the alpha 1 subunit of the L-type voltage-dependent calcium channel from normal human heart. Proc. Natl. Acad. Sci. U.S.A. 90: 6228-32 [PMID:8392192]

412. Schwinger RH, Hoischen S, Reuter H and Hullin R. (1999) Regional expression and functional characterization of the L-type Ca2+-channel in myocardium from patients with end-stage heart failure and in non-failing human hearts. J. Mol. Cell. Cardiol. 31: 283-96 [PMID:10072735]

413. Scott VE, De Waard M, Liu H, Gurnett CA, Venzke DP, Lennon VA and Campbell KP. (1996) Beta subunit heterogeneity in N-type Ca2+ channels. J. Biol. Chem. 271: 3207-12 [PMID:8621722]

414. Seino S, Chen L, Seino M, Blondel O, Takeda J, Johnson JH and Bell GI. (1992) Cloning of the alpha 1 subunit of a voltage-dependent calcium channel expressed in pancreatic beta cells. Proc. Natl. Acad. Sci. U.S.A. 89: 584-8 [PMID:1309948]

415. Seisenberger C, Specht V, Welling A, Platzer J, Pfeifer A, Kühbandner S, Striessnig J, Klugbauer N, Feil R and Hofmann F. (2000) Functional embryonic cardiomyocytes after disruption of the L-type alpha1C (Cav1.2) calcium channel gene in the mouse. J. Biol. Chem. 275: 39193-9 [PMID:10973973]

416. Shaltiel L, Paparizos C, Fenske S, Hassan S, Gruner C, Rötzer K, Biel M and Wahl-Schott CA. (2012) Complex regulation of voltage-dependent activation and inactivation properties of retinal voltage-gated Cav1.4 L-type Ca2+ channels by Ca2+-binding protein 4 (CaBP4). J. Biol. Chem. 287: 36312-21 [PMID:22936811]

417. Shcheglovitov AK, Boldyrev AI, Lyubanova OP, Shuba YM and . (2005) Peculiarities of selectivity of three subtypes of low-threshold T-type calcium channels. Neurophysiology 37: 277-286

418. Shcheglovitov AK, Boldyrev Al, Lyubanova OP, Shuba YM and . (2005) Peculiarities of selectivity of three subtypes of low-threshold T-type calcium channels. Neurophysiology 37: 277-286

419. Shcheglovitov AK, Boldyrev Al, Lyubanova OP, Shuba YM and . (2005) Peculiarities of selectivity of three subtypes of low-threshold T-type calcium channels. Neurophysiology 37: 277-286

420. Shcheglovitov AK, Boldyrev Al, Lyubanova OP, Shuba YM and . (2005) Peculiarities of selectivity of three subtypes of low-threshold T-type calcium channels. Neurophysiology 37: 277-286

421. Shcheglovitov AK, Boldyrev Al, Lyubanova OP, Shuba YM and . (2005) Peculiarities of selectivity of three subtypes of low-threshold T-type calcium channels. Neurophysiology 37: 277-286

422. Shcheglovitov AK, Boldyrev Al, Lyubanova OP, Shuba YM and . (2005) Peculiarities of selectivity of three subtypes of low-threshold T-type calcium channels. Neurophysiology 37: 277-286

423. Shcheglovitov AK, Boldyrev AI, Lyubanova OP, Shuba YM and . (2005) Peculiarities of selectivity of three subtypes of low-threshold T-type calcium channels. Neurophysiology 37: 277-286

424. Shcheglovitov AK, Boldyrev Al, Lyubanova OP, Shuba YM and . (2005) Peculiarities of selectivity of three subtypes of low-threshold T-type calcium channels. Neurophysiology 37: 277-286

425. Shcheglovitov AK, Boldyrev Al, Lyubanova OP, Shuba YM and . (2005) Peculiarities of selectivity of three subtypes of low-threshold T-type calcium channels. Neurophysiology 37: 277-286

426. Shen Y, Yu D, Hiel H, Liao P, Yue DT, Fuchs PA and Soong TW. (2006) Alternative splicing of the $\mathrm{Ca}(\mathrm{v}) 1.3$ channel IQ domain, a molecular switch for Ca2+-dependent inactivation within auditory hair cells. J. Neurosci. 26: 10690-9 [PMID:17050708]

427. Shi L, Jian K, Ko ML, Trump D and Ko GY. (2009) Retinoschisin, a new binding partner for L-type voltagegated calcium channels in the retina. J. Biol. Chem. 284: 3966-75 [PMID:19074145]

428. Shimizu M, Ogawa K, Sasaki H, Uehara Y, Otsuka Y, Okumura H, Kusaka M, Hasuda T, Yamada T and Mochizuki S. (2003) Effects of efonidipine, an L- and T-Type dual calcium channel blocker, on heart rate and blood pressure in patients with mild to severe hypertension: an uncontrolled, open-label pilot study. 
Curr Ther Res Clin Exp 64: 707-14 [PMID:24944418]

429. Sidach SS and Mintz IM. (2002) Kurtoxin, a gating modifier of neuronal high- and low-threshold ca channels. J. Neurosci. 22: 2023-34 [PMID:11896142]

430. Singh A, Gebhart M, Fritsch R, Sinnegger-Brauns MJ, Poggiani C, Hoda JC, Engel J, Romanin C, Striessnig J and Koschak A. (2008) Modulation of voltage- and Ca2+-dependent gating of CaV1.3 L-type calcium channels by alternative splicing of a C-terminal regulatory domain. J. Biol. Chem. 283: 20733-44 [PMID:18482979]

431. Singh A, Hamedinger D, Hoda JC, Gebhart M, Koschak A, Romanin C and Striessnig J. (2006) C-terminal modulator controls Ca2+-dependent gating of $\mathrm{Ca}(\mathrm{v}) 1.4 \mathrm{~L}$-type Ca2+ channels. Nat. Neurosci. 9: 1108-16 [PMID:16921373]

432. Sinnegger-Brauns MJ, Hetzenauer A, Huber IG, Renström E, Wietzorrek G, Berjukov S, Cavalli M, Walter $D$, Koschak $A$ and Waldschütz $R$ et al.. (2004) Isoform-specific regulation of mood behavior and pancreatic beta cell and cardiovascular function by L-type Ca 2+ channels. J. Clin. Invest. 113: 1430-9 [PMID:15146240]

433. Sinnegger-Brauns MJ, Huber IG, Koschak A, Wild C, Obermair GJ, Einzinger U, Hoda JC, Sartori SB and Striessnig J. (2009) Expression and 1,4-dihydropyridine-binding properties of brain L-type calcium channel isoforms. Mol. Pharmacol. 75: 407-14 [PMID:19029287]

434. Siwek ME, Müller R, Henseler C, Broich K, Papazoglou A and Weiergräber M. (2014) The CaV2.3 R-type voltage-gated $\mathrm{Ca}$ 2+ channel in mouse sleep architecture. Sleep 37: 881-92 [PMID:24790266]

435. Sluka KA. (1997) Blockade of calcium channels can prevent the onset of secondary hyperalgesia and allodynia induced by intradermal injection of capsaicin in rats. Pain 71: 157-64 [PMID:9211477]

436. Sluka KA. (1998) Blockade of N- and P/Q-type calcium channels reduces the secondary heat hyperalgesia induced by acute inflammation. J. Pharmacol. Exp. Ther. 287: 232-7 [PMID:9765342]

437. Smith MT, Cabot PJ, Ross FB, Robertson AD and Lewis RJ. (2002) The novel N-type calcium channel blocker, AM336, produces potent dose-dependent antinociception after intrathecal dosing in rats and inhibits substance $P$ release in rat spinal cord slices. Pain 96: 119-27 [PMID:11932068]

438. Snutch TP, Leonard JP, Gilbert MM, Lester HA and Davidson N. (1990) Rat brain expresses a heterogeneous family of calcium channels. Proc. Natl. Acad. Sci. U.S.A. 87: 3391-5 [PMID:1692134]

439. Sochivko D, Pereverzev A, Smyth N, Gissel C, Schneider T and Beck H. (2002) The $\mathrm{Ca}(\mathrm{V}) 2.3 \mathrm{Ca}(2+)$ channel subunit contributes to R-type $\mathrm{Ca}(2+)$ currents in murine hippocampal and neocortical neurones. $J$. Physiol. (Lond.) 542: 699-710 [PMID:12154172]

440. Soldatov NM, Zühlke RD, Bouron A and Reuter H. (1997) Molecular structures involved in L-type calcium channel inactivation. Role of the carboxyl-terminal region encoded by exons 40-42 in alpha1C subunit in the kinetics and Ca2+ dependence of inactivation. J. Biol. Chem. 272: 3560-6 [PMID:9013606]

441. Song H, Nie L, Rodriguez-Contreras A, Sheng ZH and Yamoah EN. (2003) Functional interaction of auxiliary subunits and synaptic proteins with $\mathrm{Ca}(\mathrm{v}) 1.3$ may impart hair cell $\mathrm{Ca} 2+$ current properties. $J$. Neurophysiol. 89: 1143-9 [PMID:12574487]

442. Soong TW, DeMaria CD, Alvania RS, Zweifel LS, Liang MC, Mittman S, Agnew WS and Yue DT. (2002) Systematic identification of splice variants in human P/Q-type channel alpha1(2.1) subunits: implications for current density and Ca2+-dependent inactivation. J. Neurosci. 22: 10142-52 [PMID:12451115]

443. Soong TW, Stea A, Hodson CD, Dubel SJ, Vincent SR and Snutch TP. (1993) Structure and functional expression of a member of the low voltage-activated calcium channel family. Science 260: 1133-6 [PMID:8388125]

444. Spacey SD, Hildebrand ME, Materek LA, Bird TD and Snutch TP. (2004) Functional implications of a novel EA2 mutation in the P/Q-type calcium channel. Ann. Neurol. 56: 213-20 [PMID:15293273]

445. Spacey SD, Materek LA, Szczygielski BI and Bird TD. (2005) Two novel CACNA1A gene mutations associated with episodic ataxia type 2 and interictal dystonia. Arch. Neurol. 62: 314-6 [PMID:15710862]

446. Splawski I, Timothy KW, Decher N, Kumar P, Sachse FB, Beggs AH, Sanguinetti MC and Keating MT. (2005) Severe arrhythmia disorder caused by cardiac L-type calcium channel mutations. Proc. Natl. Acad. Sci. U.S.A. 102: 8089-96; discussion 8086-8 [PMID:15863612]

447. Splawski I, Timothy KW, Sharpe LM, Decher N, Kumar P, Bloise R, Napolitano C, Schwartz PJ, Joseph $\mathrm{RM}$ and Condouris $\mathrm{K}$ et al.. (2004) $\mathrm{Ca}(\mathrm{V}) 1.2$ calcium channel dysfunction causes a multisystem disorder including arrhythmia and autism. Cell 119: 19-31 [PMID:15454078]

448. Splawski I, Yoo DS, Stotz SC, Cherry A, Clapham DE and Keating MT. (2006) CACNA1H mutations in autism spectrum disorders. J. Biol. Chem. 281: 22085-91 [PMID:16754686]

449. Staats PS, Yearwood T, Charapata SG, Presley RW, Wallace MS, Byas-Smith M, Fisher R, Bryce DA, Mangieri EA and Luther RR et al.. (2004) Intrathecal ziconotide in the treatment of refractory pain in patients with cancer or AIDS: a randomized controlled trial. JAMA 291: 63-70 [PMID:14709577]

450. Stam AH, Vanmolkot KR, Kremer HP, Gärtner J, Brown J, Leshinsky-Silver E, Gilad R, Kors EE, Frankhuizen WS and Ginjaar HB et al.. (2008) CACNA1A R1347Q: a frequent recurrent mutation in hemiplegic migraine. Clin. Genet. 74: 481-5 [PMID:18400034]

451. Starr TV, Prystay W and Snutch TP. (1991) Primary structure of a calcium channel that is highly expressed in the rat cerebellum. Proc. Natl. Acad. Sci. U.S.A. 88: 5621-5 [PMID:1648226]

452. Stea A, Dubel SJ and Snutch TP. (1999) alpha 1B N-type calcium channel isoforms with distinct biophysical properties. Ann. N. Y. Acad. Sci. 868: 118-30 [PMID:10414290]

453. Stea A, Tomlinson WJ, Soong TW, Bourinet E, Dubel SJ, Vincent SR and Snutch TP. (1994) Localization and functional properties of a rat brain alpha $1 \mathrm{~A}$ calcium channel reflect similarities to neuronal $\mathrm{Q}$ - and $\mathrm{P}$ - 
type channels. Proc. Natl. Acad. Sci. U.S.A. 91: 10576-80 [PMID:7524096]

454. Stockner T and Koschak A. (2013) What can naturally occurring mutations tell us about $\mathrm{Ca}(\mathrm{v}) 1 . \mathrm{x}$ channel function? Biochim. Biophys. Acta 1828: 1598-607 [PMID:23219801]

455. Stokes L, Gordon J and Grafton G. (2004) Non-voltage-gated L-type Ca2+ channels in human T cells: pharmacology and molecular characterization of the major alpha pore-forming and auxiliary beta-subunits. J. Biol. Chem. 279: 19566-73 [PMID:14981074]

456. Strauss O, Buss F, Rosenthal R, Fischer D, Mergler S, Stumpff F and Thieme H. (2000) Activation of neuroendocrine L-type channels (alpha1D subunits) in retinal pigment epithelial cells and brain neurons by pp60(c-src). Biochem. Biophys. Res. Commun. 270: 806-10 [PMID:10772906]

457. Striessnig J. (1999) Pharmacology, structure and function of cardiac L-type Ca(2+) channels.Cell. Physiol. Biochem. 9: 242-69 [PMID:10575201]

458. Striessnig J, Bolz HJ and Koschak A. (2010) Channelopathies in Cav1.1, Cav1.3, and Cav1.4 voltagegated L-type Ca2+ channels. Pflugers Arch. 460: 361-74 [PMID:20213496]

459. Striessnig J, Hoda JC, Koschak A, Zaghetto F, Müllner C, Sinnegger-Brauns MJ, Wild C, Watschinger K, Trockenbacher A and Pelster G. (2004) L-type Ca2+ channels in Ca2+ channelopathies. Biochem. Biophys. Res. Commun. 322: 1341-6 [PMID:15336981]

460. Strom TM, Nyakatura G, Apfelstedt-Sylla E, Hellebrand H, Lorenz B, Weber BH, Wutz K, Gutwillinger N, Rüther K and Drescher B et al.. (1998) An L-type calcium-channel gene mutated in incomplete X-linked congenital stationary night blindness. Nat. Genet. 19: 260-3 [PMID:9662399]

461. Sutton KG, Siok C, Stea A, Zamponi GW, Heck SD, Volkmann RA, Ahlijanian MK and Snutch TP. (1998) Inhibition of neuronal calcium channels by a novel peptide spider toxin, DW13.3. Mol. Pharmacol. 54: 40718 [PMID:9687583]

462. Swensen AM, Herrington J, Bugianesi RM, Dai G, Haedo RJ, Ratliff KS, Smith MM, Warren VA, Arneric SP and Eduljee $C$ et al.. (2012) Characterization of the substituted N-triazole oxindole TROX-1, a smallmolecule, state-dependent inhibitor of $\mathrm{Ca}(\mathrm{V}) 2$ calcium channels. Mol. Pharmacol. 81: 488-97 [PMID:22188924]

463. Takahara A. (2009) Cilnidipine: a new generation Ca channel blocker with inhibitory action on sympathetic neurotransmitter release. Cardiovasc Ther 27: 124-39 [PMID:19426250]

464. Takahashi M, Seagar MJ, Jones JF, Reber BF and Catterall WA. (1987) Subunit structure of dihydropyridine-sensitive calcium channels from skeletal muscle. Proc Natl Acad Sci U S A84: 5478-82 [PMID:2440051]

465. Takahashi T and Momiyama A. (1993) Different types of calcium channels mediate central synaptic transmission. Nature 366: 156-8 [PMID:7901765]

466. Takahashi Y, Jeong SY, Ogata K, Goto J, Hashida H, Isahara K, Uchiyama Y and Kanazawa I. (2003) Human skeletal muscle calcium channel alpha1S is expressed in the basal ganglia: distinctive expression pattern among L-type Ca2+ channels. Neurosci. Res. 45: 129-37 [PMID:12507731]

467. Talley EM, Cribbs LL, Lee JH, Daud A, Perez-Reyes E and Bayliss DA. (1999) Differential distribution of three members of a gene family encoding low voltage-activated (T-type) calcium channels. J. Neurosci. 19: 1895-911 [PMID:10066243]

468. Talley EM, Solórzano G, Depaulis A, Perez-Reyes E and Bayliss DA. (2000) Low-voltage-activated calcium channel subunit expression in a genetic model of absence epilepsy in the rat. Brain Res. Mol. Brain Res. 75: 159-65 [PMID:10648900]

469. Tan BZ, Jiang F, Tan MY, Yu D, Huang H, Shen Y and Soong TW. (2011) Functional characterization of alternative splicing in the $C$ terminus of L-type CaV1.3 channels. J. Biol. Chem. 286: 42725-35 [PMID:21998309]

470. Tanabe T, Beam KG, Powell JA and Numa S. (1988) Restoration of excitation-contraction coupling and slow calcium current in dysgenic muscle by dihydropyridine receptor complementary DNA. Nature 336: 134-9 [PMID:2903448]

471. Tang L, Gamal El-Din TM, Lenaeus MJ, Zheng N and Catterall WA. (2019) Structural Basis for Diltiazem Block of a Voltage-Gated $\mathrm{Ca}^{2+}$ Channel. Mol. Pharmacol. 96: 485-492 [PMID:31391290]

472. Tang L, Gamal El-Din TM, Payandeh J, Martinez GQ, Heard TM, Scheuer T, Zheng N and Catterall WA. (2014) Structural basis for $\mathrm{Ca}$ + selectivity of a voltage-gated calcium channel. Nature 505: 56-61 [PMID:24270805]

473. Tang L, Gamal El-Din TM, Swanson TM, Pryde DC, Scheuer T, Zheng N and Catterall WA. (2016) Structural basis for inhibition of a voltage-gated $\mathrm{Ca}^{2+}$ channel by $\mathrm{Ca}^{2+}$ antagonist drugs. Nature 537: 117121 [PMID:27556947]

474. Tang ZZ, Yarotskyy V, Wei L, Sobczak K, Nakamori M, Eichinger K, Moxley RT, Dirksen RT and Thornton CA. (2012) Muscle weakness in myotonic dystrophy associated with misregulated splicing and altered gating of $\mathrm{Ca}(\mathrm{V}) 1.1$ calcium channel. Hum. Mol. Genet. 21: 1312-24 [PMID:22140091]

475. Thomsen MB, Wang C, Ozgen N, Wang HG, Rosen MR and Pitt GS. (2009) Accessory subunit KChIP2 modulates the cardiac L-type calcium current. Circ. Res. 104: 1382-9 [PMID:19461043]

476. Tippens AL and Lee A. (2007) Caldendrin, a neuron-specific modulator of Cav/1.2 (L-type) Ca2+ channels. J. Biol. Chem. 282: 8464-73 [PMID:17224447]

477. Tiwari S, Zhang Y, Heller J, Abernethy DR and Soldatov NM. (2006) Atherosclerosis-related molecular alteration of the human CaV1.2 calcium channel alpha1C subunit. Proc. Natl. Acad. Sci. U.S.A. 103: 17024-9 [PMID:17071743]

478. Tonelli A, D'Angelo MG, Salati R, Villa L, Germinasi C, Frattini T, Meola G, Turconi AC, Bresolin N and 
Bassi MT. (2006) Early onset, non fluctuating spinocerebellar ataxia and a novel missense mutation in CACNA1A gene. J. Neurol. Sci. 241: 13-7 [PMID:16325861]

479. Toppin PJ, Chandy TT, Ghanekar A, Kraeva N, Beattie WS and Riazi S. (2010) A report of fulminant malignant hyperthermia in a patient with a novel mutation of the CACNA1S gene. Can J Anaesth 57: 68993 [PMID:20431982]

480. Toru S, Murakoshi T, Ishikawa K, Saegusa H, Fujigasaki H, Uchihara T, Nagayama S, Osanai M, Mizusawa $\mathrm{H}$ and Tanabe T. (2000) Spinocerebellar ataxia type 6 mutation alters P-type calcium channel function. J. Biol. Chem. 275: 10893-8 [PMID:10753886]

481. Tottene A, Fellin T, Pagnutti S, Luvisetto S, Striessnig J, Fletcher C and Pietrobon D. (2002) Familial hemiplegic migraine mutations increase $\mathrm{Ca}(2+)$ influx through single human $\mathrm{CaV} 2.1$ channels and decrease maximal CaV2.1 current density in neurons. Proc. Natl. Acad. Sci. U.S.A. 99: 13284-9 [PMID:12235360]

482. Tottene A, Pivotto F, Fellin T, Cesetti T, van den Maagdenberg AM and Pietrobon D. (2005) Specific kinetic alterations of human CaV2.1 calcium channels produced by mutation S218L causing familial hemiplegic migraine and delayed cerebral edema and coma after minor head trauma. J. Biol. Chem. 280: 17678-86 [PMID:15743764]

483. Tottene A, Volsen S and Pietrobon D. (2000) alpha(1E) subunits form the pore of three cerebellar R-type calcium channels with different pharmacological and permeation properties. J. Neurosci. 20: 171-8 [PMID:10627594]

484. Treinys R, Kaselis A, Jover E, Bagnard D and Šatkauskas S. (2014) R-type calcium channels are crucial for semaphorin 3A-induced DRG axon growth cone collapse. PLoS ONE 9: e102357 [PMID:25032951]

485. Tringham E, Powell KL, Cain SM, Kuplast K, Mezeyova J, Weerapura M, Eduljee C, Jiang X, Smith P and Morrison JL et al.. (2012) T-type calcium channel blockers that attenuate thalamic burst firing and suppress absence seizures. Sci Transl Med 4: 121ra19 [PMID:22344687]

486. Trombetta M, Bonetti S, Boselli M, Turrini F, Malerba G, Trabetti E, Pignatti P, Bonora E and Bonadonna RC. (2012) CACNA1E variants affect beta cell function in patients with newly diagnosed type 2 diabetes. the Verona newly diagnosed type 2 diabetes study (VNDS) 3. PLoS ONE 7: e32755 [PMID:22427875]

487. Tsakiridou E, Bertollini L, de Curtis M, Avanzini G and Pape HC. (1995) Selective increase in T-type calcium conductance of reticular thalamic neurons in a rat model of absence epilepsy. J. Neurosci. 15: 3110-7 [PMID:7722649]

488. Tsien RW, Lipscombe D, Madison D, Bley K and Fox A. (1995) Reflections on Ca(2+)-channel diversity, 1988-1994. Trends Neurosci. 18: 52-4 [PMID:7537405]

489. Tsunemi T, Saegusa H, Ishikawa K, Nagayama S, Murakoshi T, Mizusawa H and Tanabe T. (2002) Novel Cav2.1 splice variants isolated from Purkinje cells do not generate P-type Ca2+ current. J. Biol. Chem. 277: 7214-21 [PMID:11756409]

490. Tuluc P, Molenda N, Schlick B, Obermair GJ, Flucher BE and Jurkat-Rott K. (2009) A CaV1.1 Ca2+ channel splice variant with high conductance and voltage-sensitivity alters EC coupling in developing skeletal muscle. Biophys. J. 96: 35-44 [PMID:19134469]

491. Turner TJ, Adams ME and Dunlap K. (1992) Calcium channels coupled to glutamate release identified by omega-Aga-IVA. Science 258: 310-3 [PMID:1357749]

492. Turner TJ, Adams ME and Dunlap K. (1993) Multiple Ca2+ channel types coexist to regulate synaptosomal neurotransmitter release. Proc. Natl. Acad. Sci. U.S.A. 90: 9518-22 [PMID:8415733]

493. Tzour A, Sosial E, Meir T, Canello T, Naveh-Many T, Gabizon R and Nussinovitch I. (2013) Multiple pathways for high voltage-activated $\mathrm{ca}(2+)$ influx in anterior pituitary lactotrophs and somatotrophs. J. Neuroendocrinol. 25: 76-86 [PMID:22882461]

494. Uchitel OD, Protti DA, Sanchez V, Cherksey BD, Sugimori M and Llinás R. (1992) P-type voltagedependent calcium channel mediates presynaptic calcium influx and transmitter release in mammalian synapses. Proc. Natl. Acad. Sci. U.S.A. 89: 3330-3 [PMID:1348859]

495. Uebele VN, Nuss CE, Renger JJ and Connolly TM. (2004) Role of voltage-gated calcium channels in potassium-stimulated aldosterone secretion from rat adrenal zona glomerulosa cells. J. Steroid Biochem. Mol. Biol. 92: 209-18 [PMID:15555914]

496. Vaeth M and Feske S. (2018) Ion channelopathies of the immune system.Curr. Opin. Immunol. 52: 39-50 [PMID:29635109]

497. Vahedi K, Denier C, Ducros A, Bousson V, Levy C, Chabriat H, Haguenau M, Tournier-Lasserve E and Bousser MG. (2000) CACNA1A gene de novo mutation causing hemiplegic migraine, coma, and cerebellar atrophy. Neurology 55: 1040-2 [PMID:11061267]

498. Vajna R, Schramm M, Pereverzev A, Arnhold S, Grabsch H, Klöckner U, Perez-Reyes E, Hescheler J and Schneider T. (1998) New isoform of the neuronal Ca2+ channel alpha1E subunit in islets of Langerhans and kidney--distribution of voltage-gated $\mathrm{Ca} 2+$ channel alpha1 subunits in cell lines and tissues. Eur. J. Biochem. 257: 274-85 [PMID:9799129]

499. van den Maagdenberg AM, Kors EE, Brunt ER, van Paesschen W, Pascual J, Ravine D, Keeling S, Vanmolkot KR, Vermeulen FL and Terwindt GM et al.. (2002) Episodic ataxia type 2. Three novel truncating mutations and one novel missense mutation in the CACNA1A gene. J. Neurol. 249: 1515-9 [PMID:12420090]

500. van den Maagdenberg AM, Pietrobon D, Pizzorusso T, Kaja S, Broos LA, Cesetti T, van de Ven RC, Tottene A, van der Kaa J and Plomp JJ et al.. (2004) A Cacna1a knockin migraine mouse model with increased susceptibility to cortical spreading depression. Neuron 41: 701-10 [PMID:15003170]

501. Vandael DH, Zuccotti A, Striessnig J and Carbone E. (2012) Ca(V)1.3-driven SK channel activation 
regulates pacemaking and spike frequency adaptation in mouse chromaffin cells. J. Neurosci. 32: 1634559 [PMID:23152617]

502. Venance SL, Cannon SC, Fialho D, Fontaine B, Hanna MG, Ptacek LJ, Tristani-Firouzi M, Tawil R, Griggs $\mathrm{RC}$ and $\mathrm{CINCH}$ investigators. (2006) The primary periodic paralyses: diagnosis, pathogenesis and treatment. Brain 129: 8-17 [PMID:16195244]

503. Vieira LB, Kushmerick C, Hildebrand ME, Garcia E, Stea A, Cordeiro MN, Richardson M, Gomez MV and Snutch TP. (2005) Inhibition of high voltage-activated calcium channels by spider toxin PnTx3-6. J. Pharmacol. Exp. Ther. 314: 1370-7 [PMID:15933156]

504. Vignali S, Leiss V, Karl R, Hofmann F and Welling A. (2006) Characterization of voltage-dependent sodium and calcium channels in mouse pancreatic A- and B-cells. J. Physiol. (Lond.) 572: 691-706 [PMID:16513675]

505. Vila-Pueyo M, Gené GG, Flotats-Bastardes M, Elorza X, Sintas C, Valverde MA, Cormand B, FernándezFernández JM and Macaya A. (2014) A loss-of-function CACNA1A mutation causing benign paroxysmal torticollis of infancy. Eur. J. Paediatr. Neurol. 18: 430-3 [PMID:24445160]

506. Vitko I, Chen Y, Arias JM, Shen Y, Wu XR and Perez-Reyes E. (2005) Functional characterization and neuronal modeling of the effects of childhood absence epilepsy variants of CACNA1H, a T-type calcium channel. J. Neurosci. 25: 4844-55 [PMID:15888660]

507. Wahl-Schott C, Baumann L, Cuny H, Eckert C, Griessmeier K and Biel M. (2006) Switching off calciumdependent inactivation in L-type calcium channels by an autoinhibitory domain. Proc. Natl. Acad. Sci. U.S.A. 103: 15657-62 [PMID:17028172]

508. Wallace SJ. (1986) Use of ethosuximide and valproate in the treatment of epilepsy Neurologic clinics 4: 601-16 [PMID:3092003]

509. Wan J, Khanna R, Sandusky M, Papazian DM, Jen JC and Baloh RW. (2005) CACNA1A mutations causing episodic and progressive ataxia alter channel trafficking and kinetics. Neurology 64: 2090-7 [PMID:15985579]

510. Wang G, Dayanithi G, Newcomb R and Lemos JR. (1999) An R-type Ca(2+) current in neurohypophysial terminals preferentially regulates oxytocin secretion. J. Neurosci. 19: 9235-41 [PMID:10531427]

511. Wang H, Zhang X, Xue L, Xing J, Jouvin MH, Putney JW, Anderson MP, Trebak M and Kinet JP. (2016) Low-Voltage-Activated CaV3.1 Calcium Channels Shape T Helper Cell Cytokine Profiles. Immunity 44: 782-94 [PMID:27037192]

512. Wang HG, George MS, Kim J, Wang C and Pitt GS. (2007) Ca2+/calmodulin regulates trafficking of $\mathrm{Ca}(\mathrm{V}) 1.2 \mathrm{Ca} 2+$ channels in cultured hippocampal neurons. J. Neurosci. 27: 9086-93 [PMID:17715345]

513. Wang Q, Gao Y, Li S, Guo X and Zhang Q. (2012) Mutation screening of TRPM1, GRM6, NYX and CACNA1F genes in patients with congenital stationary night blindness. Int. J. Mol. Med. 30: 521-6 [PMID:22735794]

514. Wang S and Cortes CJ. (2020) Interactions with PDZ proteins diversify voltage-gated calcium channel signaling. J Neurosci Res [PMID:32476168]

515. Wang X, Gao G, Guo K, Yarotskyy V, Huang C, Elmslie KS and Peterson BZ. (2010) Phospholemman modulates the gating of cardiac L-type calcium channels. Biophys. J. 98: 1149-59 [PMID:20371314]

516. Wang Y, Deng X, Mancarella S, Hendron E, Eguchi S, Soboloff J, Tang XD and Gill DL. (2010) The calcium store sensor, STIM1, reciprocally controls Orai and CaV1.2 channels. Science 330: 105-9 [PMID:20929813]

517. Wang YX, Pettus M, Gao D, Phillips C and Scott Bowersox S. (2000) Effects of intrathecal administration of ziconotide, a selective neuronal $\mathrm{N}$-type calcium channel blocker, on mechanical allodynia and heat hyperalgesia in a rat model of postoperative pain. Pain 84: 151-8 [PMID:10666519]

518. Wappl E, Koschak A, Poteser M, Sinnegger MJ, Walter D, Eberhart A, Groschner K, Glossmann H, Kraus $\mathrm{RL}$ and Grabner M et al.. (2002) Functional consequences of P/Q-type Ca2+ channel Cav2.1 missense mutations associated with episodic ataxia type 2 and progressive ataxia. J. Biol. Chem. 277: 6960-6 [PMID:11742003]

519. Watanabe M, Sakuma $Y$ and Kato M. (2004) High expression of the R-type voltage-gated Ca2+ channel and its involvement in Ca2+-dependent gonadotropin-releasing hormone release in GT1-7 cells. Endocrinology 145: 2375-83 [PMID:14736732]

520. Wegener JW, Schulla V, Koller A, Klugbauer N, Feil R and Hofmann F. (2006) Control of intestinal motility by the $\mathrm{Ca}(\mathrm{v}) 1.2$ L-type calcium channel in mice. FASEB J. 20: 1260-2 [PMID:16636102]

521. Wegener JW, Schulla V, Lee TS, Koller A, Feil S, Feil R, Kleppisch T, Klugbauer N, Moosmang S and Welling A et al.. (2004) An essential role of Cav1.2 L-type calcium channel for urinary bladder function. FASEB J. 18: 1159-61 [PMID:15132976]

522. Weick JP, Groth RD, Isaksen AL and Mermelstein PG. (2003) Interactions with PDZ proteins are required for L-type calcium channels to activate cAMP response element-binding protein-dependent gene expression. J. Neurosci. 23: 3446-56 [PMID:12716953]

523. Weiergräber M, Henry M, Radhakrishnan K, Hescheler J and Schneider T. (2007) Hippocampal seizure resistance and reduced neuronal excitotoxicity in mice lacking the Cav2.3 E/R-type voltage-gated calcium channel. J. Neurophysiol. 97: 3660-9 [PMID:17376845]

524. Weleber RG. (2002) Infantile and childhood retinal blindness: a molecular perspective (The Franceschetti Lecture). Ophthalmic Genet. 23: 71-97 [PMID:12187427]

525. Wennemuth G, Westenbroek RE, Xu T, Hille B and Babcock DF. (2000) CaV2.2 and CaV2.3 (N- and Rtype) Ca2+ channels in depolarization-evoked entry of Ca2+ into mouse sperm. J. Biol. Chem. 275: 21210- 
7 [PMID:10791962]

526. Westenbroek RE and Babcock DF. (1999) Discrete regional distributions suggest diverse functional roles of calcium channel alpha1 subunits in sperm. Dev. Biol. 207: 457-69 [PMID:10068476]

527. Westenbroek RE, Bausch SB, Lin RC, Franck JE, Noebels JL and Catterall WA. (1998) Upregulation of Ltype $\mathrm{Ca} 2+$ channels in reactive astrocytes after brain injury, hypomyelination, and ischemia. J. Neurosci. 18: 2321-34 [PMID:9502793]

528. Westenbroek RE, Hell JW, Warner C, Dubel SJ, Snutch TP and Catterall WA. (1992) Biochemical properties and subcellular distribution of an $\mathrm{N}$-type calcium channel alpha 1 subunit. Neuron 9: 1099-115 [PMID:1334419]

529. Westenbroek RE, Hoskins $L$ and Catterall WA. (1998) Localization of Ca2+ channel subtypes on rat spinal motor neurons, interneurons, and nerve terminals. J. Neurosci. 18: 6319-30 [PMID:9698323]

530. Westenbroek RE, Sakurai T, Elliott EM, Hell JW, Starr TV, Snutch TP and Catterall WA. (1995) Immunochemical identification and subcellular distribution of the alpha $1 \mathrm{~A}$ subunits of brain calcium channels. J. Neurosci. 15: 6403-18 [PMID:7472404]

531. White JA, McKinney BC, John MC, Powers PA, Kamp TJ and Murphy GG. (2008) Conditional forebrain deletion of the L-type calcium channel Ca $\vee 1.2$ disrupts remote spatial memories in mice. Learn. Mem. 15: 1-5 [PMID:18174367]

532. Williams JA, Day M and Heavner JE. (2008) Ziconotide: an update and review.Expert Opin Pharmacother 9: 1575-83 [PMID:18518786]

533. Williams ME, Brust PF, Feldman DH, Patthi S, Simerson S, Maroufi A, McCue AF, Veliçelebi G, Ellis SB and Harpold MM. (1992) Structure and functional expression of an omega-conotoxin-sensitive human Ntype calcium channel. Science 257: 389-95 [PMID:1321501]

534. Williams ME, Marubio LM, Deal CR, Hans M, Brust PF, Philipson LH, Miller RJ, Johnson EC, Harpold MM and Ellis SB. (1994) Structure and functional characterization of neuronal alpha $1 \mathrm{E}$ calcium channel subtypes. J. Biol. Chem. 269: 22347-57 [PMID:8071363]

535. Williams ME, Washburn MS, Hans M, Urrutia A, Brust PF, Prodanovich P, Harpold MM and Stauderman KA. (1999) Structure and functional characterization of a novel human low-voltage activated calcium channel. J. Neurochem. 72: 791-9 [PMID:9930755]

536. Willis M, Kaufmann WA, Wietzorrek G, Hutter-Paier B, Moosmang S, Humpel C, Hofmann F, Windisch M, Knaus HG and Marksteiner J. (2010) L-type calcium channel CaV 1.2 in transgenic mice overexpressing human AbetaPP751 with the London (V717I) and Swedish (K670M/N671L) mutations. J. Alzheimers Dis. 20: 1167-80 [PMID:20413896]

537. Witcher DR, De Waard M and Campbell KP. (1993) Characterization of the purified N-type Ca2+ channel and the cation sensitivity of omega-conotoxin GVIA binding. Neuropharmacology 32: 1127-39 [PMID:8107967]

538. Wiśniowska B, Mendyk A, Fijorek K, Glinka A and Polak S. (2012) Predictive model for L-type channel inhibition: multichannel block in QT prolongation risk assessment. J Appl Toxicol 32: 858-66 [PMID:22761000]

539. Wu F, Mi W, Hernández-Ochoa EO, Burns DK, Fu Y, Gray HF, Struyk AF, Schneider MF and Cannon SC. (2012) A calcium channel mutant mouse model of hypokalemic periodic paralysis. J. Clin. Invest. 122: 4580-91 [PMID:23187123]

540. Wu J, Yan Z, Li Z, Qian X, Lu S, Dong M, Zhou Q and Yan N. (2016) Structure of the voltage-gated calcium channel $\mathrm{Ca}(\mathrm{v}) 1.1$ at 3.6 Å resolution. Nature 537: 191-196 [PMID:27580036]

541. Wu J, Yan Z, Li Z, Yan C, Lu S, Dong M and Yan N. (2015) Structure of the voltage-gated calcium channel Cav1.1 complex. Science 350: aad2395 [PMID:26680202]

542. Wu LG, Borst JG and Sakmann B. (1998) R-type Ca2+ currents evoke transmitter release at a rat central synapse. Proc. Natl. Acad. Sci. U.S.A. 95: 4720-5 [PMID:9539805]

543. Wu LG and Saggau P. (1995) Block of multiple presynaptic calcium channel types by omega-conotoxinMVIIC at hippocampal CA3 to CA1 synapses. J. Neurophysiol. 73: 1965-72 [PMID:7623094]

544. Wutz K, Sauer C, Zrenner E, Lorenz B, Alitalo T, Broghammer M, Hergersberg M, de la Chapelle A, Weber BH and Wissinger B et al.. (2002) Thirty distinct CACNA1F mutations in 33 families with incomplete type of XLCSNB and Cacna1f expression profiling in mouse retina. Eur. J. Hum. Genet. 10: 449-56 [PMID:12111638]

545. Xiang Z, Thompson AD, Brogan JT, Schulte ML, Melancon BJ, Mi D, Lewis LM, Zou B, Yang L and Morrison R et al.. (2011) The Discovery and Characterization of ML218: A Novel, Centrally Active T-Type Calcium Channel Inhibitor with Robust Effects in STN Neurons and in a Rodent Model of Parkinson's Disease. ACS Chem Neurosci 2: 730-742 [PMID:22368764]

546. Xie X, Van Deusen AL, Vitko I, Babu DA, Davies LA, Huynh N, Cheng H, Yang N, Barrett PQ and PerezReyes E. (2007) Validation of high throughput screening assays against three subtypes of $\mathrm{Ca}(\mathrm{v}) 3 \mathrm{~T}$-type channels using molecular and pharmacologic approaches. Assay Drug Dev Technol 5: 191-203 [PMID:17477828]

547. Xu G, Wu H, Du B and Qin L. (2012) The efficacy and safety of cilnidipine on mild to moderate essential hypertension: a systematic review and meta-analysis of randomized controlled trials in Chinese patients. Cardiovasc Hematol Disord Drug Targets 12: 56-62 [PMID:22746347]

548. Xu H, Ginsburg KS, Hall DD, Zimmermann M, Stein IS, Zhang M, Tandan S, Hill JA, Horne MC and Bers $\mathrm{D}$ et al.. (2010) Targeting of protein phosphatases PP2A and PP2B to the C-terminus of the L-type calcium channel Ca v1.2. Biochemistry 49: 10298-307 [PMID:21053940]

549. Xu M, Welling A, Paparisto S, Hofmann F and Klugbauer N. (2003) Enhanced expression of L-type Cav1.3 
calcium channels in murine embryonic hearts from Cav1.2-deficient mice. J. Biol. Chem. 278: 40837-41 [PMID:12900400]

550. Xu W and Lipscombe D. (2001) Neuronal Ca(V)1.3alpha(1) L-type channels activate at relatively hyperpolarized membrane potentials and are incompletely inhibited by dihydropyridines. J. Neurosci. 21: 5944-51 [PMID:11487617]

551. Yang T, Puckerin A and Colecraft HM. (2012) Distinct RGK GTPases differentially use $\alpha 1$ - and auxiliary $\beta$ binding-dependent mechanisms to inhibit CaV1.2/CaV2.2 channels. PLoS ONE 7: e37079 [PMID:22590648]

552. Yokoyama K, Kurihara T, Saegusa H, Zong S, Makita K and Tanabe T. (2004) Blocking the R-type (Cav2.3) Ca2+ channel enhanced morphine analgesia and reduced morphine tolerance. Eur. J. Neurosci. 20: 3516-9 [PMID:15610184]

553. Yu FH and Catterall WA. (2004) The VGL-chanome: a protein superfamily specialized for electrical signaling and ionic homeostasis. Sci. STKE 2004: re15 [PMID:15467096]

554. Yu K, Xiao Q, Cui G, Lee A and Hartzell HC. (2008) The best disease-linked Cl- channel hBest1 regulates Ca V 1 (L-type) Ca2+ channels via src-homology-binding domains. J. Neurosci. 28: 5660-70 [PMID:18509027]

555. Yue Q, Jen JC, Nelson SF and Baloh RW. (1997) Progressive ataxia due to a missense mutation in a calcium-channel gene. Am. J. Hum. Genet.61: 1078-87 [PMID:9345107]

556. Zamponi GW. (2003) Calmodulin lobotomized: novel insights into calcium regulation of voltage-gated calcium channels. Neuron 39: 879-81 [PMID:12971887]

557. Zamponi GW. (2016) Targeting voltage-gated calcium channels in neurological and psychiatric diseases. Nat Rev Drug Discov 15: 19-34 [PMID:26542451]

558. Zamponi GW, Bourinet E and Snutch TP. (1996) Nickel block of a family of neuronal calcium channels: subtype- and subunit-dependent action at multiple sites. J. Membr. Biol. 151: 77-90 [PMID:8661496]

559. Zamponi GW, Feng ZP, Zhang L, Pajouhesh H, Ding Y, Belardetti F, Pajouhesh H, Dolphin D, Mitscher LA and Snutch TP. (2009) Scaffold-based design and synthesis of potent N-type calcium channel blockers. Bioorg. Med. Chem. Lett. 19: 6467-72 [PMID:19815411]

560. Zeitz C, Labs S, Lorenz B, Forster U, Uksti J, Kroes HY, De Baere E, Leroy BP, Cremers FP and Wittmer $\mathrm{M}$ et al.. (2009) Genotyping microarray for CSNB-associated genes. Invest. Ophthalmol. Vis. Sci. 50: 591926 [PMID:19578023]

561. Zeitz C, Minotti R, Feil S, Mátyás G, Cremers FP, Hoyng CB and Berger W. (2005) Novel mutations in CACNA1F and NYX in Dutch families with X-linked congenital stationary night blindness. Mol. Vis. 11: 17983 [PMID:15761389]

562. Zhang H, Maximov A, Fu Y, Xu F, Tang TS, Tkatch T, Surmeier DJ and Bezprozvanny I. (2005) Association of CaV1.3 L-type calcium channels with Shank. J. Neurosci. 25: 1037-49 [PMID:15689539]

563. Zhang J, Berra-Romani R, Sinnegger-Brauns MJ, Striessnig J, Blaustein MP and Matteson DR. (2007) Role of Cav1.2 L-type Ca2+ channels in vascular tone: effects of nifedipine and Mg2+. Am. J. Physiol. Heart Circ. Physiol. 292: H415-25 [PMID:16980345]

564. Zhang Q, Bengtsson M, Partridge C, Salehi A, Braun M, Cox R, Eliasson L, Johnson PR, Renström E and Schneider T et al.. (2007) R-type Ca(2+)-channel-evoked CICR regulates glucose-induced somatostatin secretion. Nat. Cell Biol. 9: 453-60 [PMID:17369816]

565. Zhang Y, Chen K, Sloan SA, Bennett ML, Scholze AR, O'Keeffe S, Phatnani HP, Guarnieri P, Caneda C and Ruderisch N et al.. (2014) An RNA-Sequencing Transcriptome and Splicing Database of Glia, Neurons, and Vascular Cells of the Cerebral Cortex. J. Neurosci. 34: 11929-47 [PMID:25186741]

566. Zhang Y, Mori M, Burgess DL and Noebels JL. (2002) Mutations in high-voltage-activated calcium channel genes stimulate low-voltage-activated currents in mouse thalamic relay neurons. J. Neurosci. 22: $6362-71$ [PMID:12151514]

567. Zhang Z, Xu Y, Song H, Rodriguez J, Tuteja D, Namkung Y, Shin HS and Chiamvimonvat N. (2002) Functional Roles of $\mathrm{Ca}(\mathrm{v}) 1.3$ (alpha(1D)) calcium channel in sinoatrial nodes: insight gained using genetargeted null mutant mice. Circ. Res. 90: 981-7 [PMID:12016264]

568. Zhao Y, Huang G, Wu J, Wu Q, Gao S, Yan Z, Lei J and Yan N. (2019) Molecular Basis for Ligand Modulation of a Mammalian Voltage-Gated $\mathrm{Ca}^{2+}$ Channel. Cell 177: 1495-1506.e12 [PMID:31150622]

569. Zhao Y, Huang G, Wu Q, Wu K, Li R, Lei J, Pan X and Yan N. (2019) Cryo-EM structures of apo and antagonist-bound human $\mathrm{Ca}_{\mathrm{v}}$ 3.1. Nature 576: 492-497 [PMID:31766050]

570. Zheng W, Rampe D and Triggle DJ. (1991) Pharmacological, radioligand binding, and electrophysiological characteristics of FPL 64176, a novel nondihydropyridine Ca2+ channel activator, in cardiac and vascular preparations. Mol. Pharmacol. 40: 734-41 [PMID:1719369]

571. Zhong X, Liu JR, Kyle JW, Hanck DA and Agnew WS. (2006) A profile of alternative RNA splicing and transcript variation of CACNA1H, a human T-channel gene candidate for idiopathic generalized epilepsies. Hum. Mol. Genet. 15: 1497-512 [PMID:16565161]

572. Zhuchenko O, Bailey J, Bonnen P, Ashizawa T, Stockton DW, Amos C, Dobyns WB, Subramony SH, Zoghbi HY and Lee CC. (1997) Autosomal dominant cerebellar ataxia (SCA6) associated with small polyglutamine expansions in the alpha 1A-voltage-dependent calcium channel. Nat Genet 15: 62-9 [PMID:8988170]

573. Zito I, Allen LE, Patel RJ, Meindl A, Bradshaw K, Yates JR, Bird AC, Erskine L, Cheetham ME and Webster AR et al.. (2003) Mutations in the CACNA1F and NYX genes in British CSNBX families Hum. Mutat. 21: 169 [PMID:12552565] 
574. Zühlke RD, Pitt GS, Deisseroth K, Tsien RW and Reuter H. (1999) Calmodulin supports both inactivation and facilitation of L-type calcium channels. Nature 399: 159-62 [PMID:10335846] 